\title{
PROPERTY, CONTRACT, AND VERIFICATION: THE NUMERUS CLAUSUS PROBLEM AND THE DIVISIBILITY OF RIGHTS
}

\author{
HENRY HANSMANN and REINIER KRAAKMAN*
}

\begin{abstract}
The law of every jurisdiction defines a set of well-recognized forms that property rights can take and restricts the creation of property rights that deviate from those forms. We argue that these restrictions serve not to standardize rights as others have argued but rather to aid verification of the ownership of rights offered for conveyance. We explore the feasible verification rules for property rights and illustrate the relationship between those rules and the structure of rights they support in the principal fields of property, including use rights to real and personal property, security interests, legal entities, and intellectual property. We offer a simple calculus for assessing the efficiency of alternative property rights regimes. We define clearly the difference between property rights and contract rights, clarify the connection between property rights and property rules, and illuminate the limits on specific performance as a contract remedy.
\end{abstract}

\section{INTRODUCTION}

$\mathbf{T}$

HE law of every jurisdiction defines a set of well-recognized forms that property rights can take and burdens the creation of property rights that deviate from those conventional forms. In this respect, property law differs from contract law, which generally leaves parties free to craft contractual rights in any form they wish. Scholars in civil law countries have long been self-conscious about the law's constraints on property rights. Only recently,

* Sam Harris Professor of Law, Yale Law School, and Ezra Ripley Thayer Professor of Law, Harvard Law School, respectively. We have benefited from comments received during presentations at the American Law and Economics Association, the University of California at Berkeley, the Comparative Law and Economics Forum, Harvard, New York University, Northwestern, Stanford, Vanderbilt, and Yale, and from a number of colleagues, including in particular Barry Adler, Anne Alstott, Richard Craswell, Rochelle Dreyfuss, Robert Ellickson, Louis Kaplow, Lance Liebman, Steven Shavell, and Teun Struycken. Earlier versions of this essay were titled, variously, "Unity of Property Rights" and "The Structure of Property Rights." 
however, have those constraints received much attention, or even acknowledgment, in the literature of the common-law countries.'

The principal effort to rationalize the law's limits on property rights takes the form of several recent articles by Thomas Merrill and Henry Smith. ${ }^{2}$ In schematic summary, those authors offer-or seem best understood as offering - the following analysis: (1) Property rights differ from contract rights by being "good against all the world." (2) Both the common law and the civil law limit property rights to a small number (numerus clausus) of welldefined types. (3) These limits serve to reduce the information-processing costs of potential purchasers of property rights in understanding precisely what they are buying and of potential tortfeasors in understanding with which property rights they must not interfere. (4) More precisely, there is an "optimal standardization" of property rights, with the appropriate number of alternative forms being determined by a trade-off between the utility of having more forms and the confusion that more forms would engender.

Merrill and Smith's contribution is important. We agree, in particular, that third-party information costs are central to the law's regulation of property rights. We disagree, however, with each of the four principal elements of the Merrill and Smith analysis. Rather, we offer the following analysis: (1) Property rights differ from contract rights in that a property right in an asset, unlike a contract right, can be enforced against subsequent transferees of other rights in the asset. That is, a property right "runs with the asset." (2) The law's limitations on property rights take the form not of standardization into a discreet number of well-defined forms, but rather of regulation of the types and degree of notice required to establish different types of property rights. (3) These limitations serve not to facilitate communication among persons who transact in rights, but rather to facilitate verification of ownership of the rights offered for conveyance. (4) Property law generally addresses the verification problem by presuming that all property rights in a given asset are held by a single owner, subject to the exception that a partitioning of property rights across more than one owner is enforceable if there has been adequate notice of that partitioning to persons whom it might affect. The degree of notice required and the extent to which the law affirmatively facilitates the giving of notice vary across different types of property rights according to the utility of the partitioning and the costs of giving

\footnotetext{
' See Bernard Rudden, Economic Theory v. Property Law: The Numerus Clausus Problem, in Oxford Essays in Jurisprudence, Third Series 239 (1987); Henry Hansmann \& Marina Santilli, Authors' and Artists' Moral Rights: A Comparative Legal and Economic Analysis, 26 J. Legal Stud. 95 (1997); Henry Hansmann \& Ugo Mattei, The Functions of Trust Law: A Comparative Legal and Economic Analysis, 73 N.Y.U. L. Rev. 434 (1998); Michael A. Heller, The Boundaries of Private Property, 108 Yale L. J. 1163, 1176-82 (1999); Thomas W. Merrill \& Henry A. Smith, Optimal Standardization in the Law of Property: The Numerus Clausus Principle, 110 Yale L. J. 1 (2000); Henry Hansmann \& Reinier Kraakman, The Essential Role of Organizational Law, 110 Yale L. J. 387, 422 (2000).

${ }^{2}$ Merrill \& Smith, supra note 1.
} 
notice. Because the benefits of partial property rights are often low and the costs of verifying those rights are generally high, property law necessarily takes an unaccommodating approach to all but a few basic categories of partial property rights.

In the course of developing our analysis, we explore the varieties of verification rules by which the law establishes the forms of notice required to establish property rights, and we illustrate the close relationship between verification rules and the forms of property rights that those rules support. We set out conditions for assessing the efficiency of alternative property rights regimes and discuss the extent to which that efficiency calculus is actually reflected in property law. We survey some of the most common categories of partial property rights and analyze the ways in which the structure of those rights reflects limits on the feasible verification rules. We also seek to clarify the relationship between property rights and contract rights, the connection between property rights and property rules, and the limits on specific performance as a remedy in contract.

\section{The Law's Restrictions on Divided Property Rights}

A person who owns an asset is generally free to grant to other persons contractual claims on that asset of any form, including rights to use the asset in any fashion desired, rights to require or to prevent specified uses of the asset by its owner, and rights that are contingent on the occurrence of some condition. The owner of an asset is not similarly free, however, to grant to other persons property rights in that asset. This is most conspicuous in the civil law countries of Europe, which since the nineteenth century have adhered self-consciously to a "unitary theory of property rights" under which, as a general rule, all property rights in an asset must be concentrated in the hands of a single owner rather than divided into partial rights shared among two or more persons. Only a relatively small, closed number (numerus clausus) of specifically defined exceptions to this principle of unitary ownership are permitted. ${ }^{3}$ These exceptions include, for example, cotenancy, servitudes on real property, mortgages on real property, and security interests in personal property. ${ }^{4}$ Partial property rights that do not conform to one of these specific exceptions are unenforceable. The private trust is a prominent example. The particular division of property rights between trustee and beneficiary that a trust involves is not among the enumerated forms of division permitted under the civil law, and hence private trusts cannot generally be established in the civil law countries of Europe. This restriction has had important practical implications; the trust form is now extensively used in U.S. financial ad-

\footnotetext{
${ }^{3}$ See John Henry Merryman, Estate and Ownership: Variations on a Theme by Lawson, 48 Tulane L. Rev. 916 (1974).

${ }^{4}$ These four types of property rights are found, for instance, in the German civil code at,

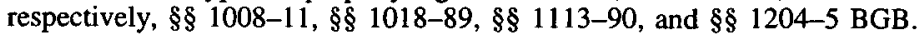


ministration, and its absence in continental Europe has been an important handicap, now often compensated for by legislative provisions for specialized property forms for asset management. ${ }^{5}$

The civil law jurisdictions are not unique, however, in restricting the division of property rights. Legal doctrine in the common-law countries, including the United States, has a similar character. The particular forms of partial property rights that the common law recognizes sometimes differ from those recognized under the civil law, as illustrated by the common law's long-standing acceptance of the private trust. Moreover, the common law's limitations on divided property rights are generally less rigid than are those of the civil law. Nevertheless, the common law, like the civil law, provides for a limited number of forms of partial property rights that can be created with relative ease and makes it difficult to enforce rights that differ from these accepted forms.

In general, the divided or partial property rights for which the common law makes explicit provision are heavily concentrated in four areas: real property (cotenancy, servitudes, condominiums, mortgages, future interests); intellectual property (copyrights, patents); security interests in personal property (chattel mortgages-now largely consolidated, in the United States, in Article 9 of the Uniform Commercial Code (U.C.C.)); and the law of legal entities (partnerships, corporations, trusts). Outside these four fields, and the specific types of property rights for which each provides, the law makes it difficult to create partial property rights. Rather, all property rights in an asset are presumed to be held by one person.

Moreover, even within the four fields just mentioned, the law tends to confine property rights to specific forms. These limitations are most obvious and familiar in the realm of real property. ${ }^{6}$ Property rights for limited uses of land, for example, have long been confined to easements, real covenants, and equitable servitudes, each with its special requirements for enforceability. ${ }^{7}$ Another conspicuous example is the condominium. Although long recognized by the civil law, and widely employed in Europe, the condominium was not accepted into U.S. property law until 1961, when individual states began adopting legislation to recognize it, and the form soon showed

\footnotetext{
${ }^{5}$ See Hansmann \& Mattei, supra note 1. As pointed out in that article, the reason that the trust involves a unique form of property rights is not that the trustee has the right and duty to manage, and to sell and purchase, property on behalf of the beneficiary; agency law suffices to grant such powers. Rather, what is special about the trust is the pattern of creditors' rights that it establishes among creditors of the trustee, of the beneficiary, and of the trust-a pattern resembling that created by a corporation. See the discussion of legal entities in Section IXB infra.

${ }^{6}$ Merrill \& Smith, supra note 1 , offers a more extended and highly informative survey of the law's limitations, with particular focus on the law of real property.

${ }^{7}$ An effort has now been made to unify and generalize these rules with the new Restatement (Third) of Property: Servitudes $\$ \S 4.1-4.13$ (2000).
} 
its value by sweeping rapidly through the housing market. ${ }^{8}$ English law, meanwhile, still declines to make provision for the condominium. ${ }^{9}$

The law of artists' rights is another area in which, like the condominium and in contrast to the trust, the common law has been more restrictive than the civil law in the forms of property it recognizes. At issue is the right of artists, such as painters and sculptors, to retain rights in their works after the works themselves (or, more precisely, rights to possession of the works) have been sold. Two such rights have particular prominence and have been the focus of recent efforts at reform in both the United States and the European Union: the "right of integrity" and resale royalty rights. These rights, although of only modest economic importance, offer a particularly nice illustration of the issues at stake in the law's recognition of property rights. Consequently, we will focus on these rights as illustrations in the course of our analysis.

The artist's right of integrity is the right of a painter, sculptor, or other artist to insist that, even after she has sold one of her works, neither the original purchaser of the work nor any subsequent owner can alter or destroy the work absent the artist's permission. Continental European law began enforcing the right of integrity in the nineteenth century. American law, however, following the usual practice in common-law jurisdictions, generally declined to recognize such a right. ${ }^{10}$ While a U.S. artist could bind the first purchaser of her work, by contract, not to alter or destroy the work, that right generally could not be made into a property right that would bind subsequent purchasers. " This was in keeping with the common-law doctrine that it is generally not possible to create "an equitable servitude on a chattel" 12 -in this case, a type of negative covenant held in gross (that is, personally) by the artist that would let the artist prevent any subsequent owner of a work of art from altering it.

\footnotetext{
${ }^{8}$ Interestingly, the condominium form was made part of U.S. law quite fortuitously, with no awareness of the great role it would subsequently play. See Henry Hansmann, Condominium and Cooperative Housing: Transactional Efficiency, Tax Subsidies, and Tenure Choice, $20 \mathrm{~J}$. Legal Stud. 25 (1991).

${ }^{9}$ See Rudden, supra note 1 , which remarks entertainingly on the substantial inconvenience this causes.

${ }^{10}$ See Hansmann \& Santilli, supra note 1.

"An example is provided by a massive mobile by Alexander Calder that was purchased by a private collector and then donated to the Pittsburgh International Airport. Over Calder's protests, the airport altered the orientation of the sculpture's elements and soldered them to prevent movement and then repainted the entire black and white sculpture in green and gold, the colors of Allegheny County. Calder tried unsuccessfully for the rest of his life to have the work restored to its original state. Diana Rose, Calder's Pittsburgh: A Violated and Immobile Mobile, Art News, January 1978, at 39. If the event had taken place after 1990, when federal legislation recognized the right of integrity, Calder could have had his way.

${ }^{12}$ On the law's general resistance to servitudes on chattels, see Zechariah Chaffee, Jr., Equitable Servitudes on Chattels, 41 Harv. L. Rev. 945 (1928); Zechariah Chaffee, Jr., The Music Goes Round and Round: Equitable Servitudes and Chattels, 69 Harv. L. Rev. 1250 (1956).
} 
The U.S. rejection of a right of integrity was not casual. The desirability of adopting affirmative legislation recognizing the right was long debated. Unwillingness to recognize the right was among the reasons why, for over a century, the United States failed to sign the Berne Convention on Copyright, which required signatory countries to recognize artists' right of integrity. The situation changed in 1990 when the United States, contemporaneously with finally signing the Berne Convention, adopted the federal Visual Artists Rights Act, which permits artists to retain a right of integrity in works they sell. ${ }^{13}$

When enacting the latter act, however, the U.S. Congress self-consciously declined to recognize a resale royalty right for artists. This right would permit an artist to claim a percentage of the price (or, alternatively, of the increase in price) that his work brings in each subsequent resale of the work from one owner to the next. A number of European countries have long provided for such a "droit de suite," and the European Union has recently adopted a directive requiring all member states to recognize the right. ${ }^{14}$ Among common-law jurisdictions, in contrast, artists' resale royalty rights are at present recognized only in the state of California. ${ }^{15}$

\section{The Distinction between Property Rights AND CONTRACT RIghtS}

To understand the law's limits on property rights, we must be clear about what property rights are and particularly about the difference between property rights and contract rights. For this purpose, it is easiest to focus on claims on assets. We will return later to explore more carefully what might qualify as an "asset." For the present, we can simply confine our attention to assets that are physical objects.

A person's claim on an asset-a right to use that asset in certain ways, for example-can take the form of either a contract right or a property right. For our purposes, the attribute that distinguishes a property right from a contract right is that a property right is enforceable, not just against the original grantor of the right, but also against other persons to whom possession of the asset, or other rights in the asset, are subsequently transferred. In the parlance of property law, the burden of a property right "runs with

\footnotetext{
${ }^{13}$ For more extensive discussion, see Hansmann \& Santilli, supra note 1. While adherence to the Berne Convention apparently helped stimulate U.S. national recognition of the right of integrity, it was not a decisive factor; other common-law countries had joined the convention without such explicit recognition of the right.

${ }^{14}$ Directive 2001/84/EC of the European Parliament and of the Council of 27 September 2001 on the Resale Right for the Benefit of the Author of an Original Work of Art, 2001 O.J. (L 272) III 0032-0036.

${ }^{15}$ See Jeffrey Perloff, Droit de Suite, in The New Palgrave Dictionary of Economics and the Law (Peter Newman ed. 1998); and Henry Hansmann \& Marina Santilli, Royalties for Artists versus Royalties for Authors and Composers, 25 J. Cultural Econ. 259-81 (2001).
} 
the asset." A tenant who rents a parcel of land therefore has a property right in the land if she can enforce her rights in the land, not just against the landlord who originally granted the lease, but also against other persons to whom the landlord subsequently transfers his own interest in the land. While this definition of a property right does not always track current usage of the term, ${ }^{16}$ we offer it as the definition that best illuminates how, and why, the law takes a more restrictive approach to property rights than it does to contract rights. We explore alternative definitions of property rights, including the one advocated by Merrill and Smith, in Section X.

The artists' right of integrity offers another clear illustration. If an artist sells a painting subject to a condition that the purchaser not alter or destroy the painting, but the artist can enforce that right only against the original purchaser to whom the artist sells the work, the artist has a mere contractual right. But if the artist can also enforce that right against subsequent thirdparty transferees of the painting, she has, by our definition, a property right in the painting.

The question we are addressing, then, is why the law limits the ability of owners of assets to grant partial rights in those assets that will run with the asset - that is, that will bind subsequent owners of the (remaining rights in) the asset. Or, as we put it earlier, why does the law limit the ways in which property rights in an asset can be divided?

\section{STANDARDIZATION AND LANGUage}

If two parties are to communicate with each other concerning property rights-particularly for purposes of describing the rights that one person is transferring (or offering to transfer) to another-it is helpful to have some standardized forms with those attributes that are most commonly desired, and conventional labels for those forms. One function served by the law of property is to define, and offer labels for, such standard forms. The term "copyright," for example, is a simple label denoting a complex package of well-defined property rights designed to serve the needs of authors and publishers. Likewise, "tenancy in common" and "joint tenancy with right of survivorship" describe two alternative standard arrangements that co-owners of property can employ.

Merrill and Smith focus on the utility of such legally defined terms-what we might call the "communicative" function of law-to explain the law's restrictive approach to property rights. If individuals were left free to create property rights of any form they wish, Merrill and Smith argue, the result would be to impose inefficiently large costs on prospective acquirers of

\footnotetext{
${ }^{16}$ For example, a lease is generally categorized as a contract and not as a property right in the civil law, even though the tenant can generally enforce the lease against subsequent transferees of the underlying fee in the civil law just as in the common law. See $\S 571$ BGB (German civil code); \& 1599 C.c. (Italian civil code).
} 
property in ascertaining the nature of the rights they are acquiring. By limiting property rights to a finite set of standard forms, they claim, the law reduces the "information-processing costs" of all persons who seek to acquire property rights. ${ }^{17}$ Given such limits, a potential purchaser of an asset need only determine which of the various standard packages of rights is being offered to him. He need not also incur the costs of determining whether some other, nonstandard package of rights is being offered him, nor need he incur the "measurement costs" of ascertaining attributes of nonstandard rights that are hard to discern. ${ }^{18}$

As the number of alternative forms of property rights increases, argue Merrill and Smith, the marginal cost to prospective acquirers of ascertaining the content of the rights they are acquiring increases. ${ }^{19}$ At the same time, as the number of available forms increases, the marginal utility of adding further forms decreases, with each additional form being designed to serve ever more uncommon or lower-value needs. Consequently, claim Merrill and Smith, there is an "optimal standardization" of property rights to a finite number of forms determined by the point at which the marginal information cost of adding another form just equals the marginal utility of the uses that would be served by the form. ${ }^{20}$

There are three basic problems with this analysis, each of which in itself renders the analysis unconvincing. The first problem is that this optimal standardization view fails to explain why property law is more restrictive than contract law. If there is an optimal finite number of standard forms for property rights, why is not the same true for contract rights? Contract law, like property law, provides parties with a variety of standard terms and default rules to facilitate communication. At the same time, contract law generally leaves parties free to deviate from those standard forms and create individually tailored contractual rights of any form and complexity they wish. Yet the utility of standard contractual terms and forms is evidently not frustrated by the continuing availability of an infinite variety of nonstandard contractual rights with unconventional and perhaps hard-to-measure characteristics.

The second problem is that, as suggested by the comparison with contract rights, it is not in fact plausible that an increase in the available menu of property rights generates a meaningful degree of confusion that in turn pro-

${ }^{17}$ Merrill \& Smith, supra note 1 , at 27.

${ }^{18}$ Id. at 26.

${ }^{19}$ Why the marginal cost, rather than just the total cost, should increase is unclear from Merrill and Smith's analysis. It is not necessary to their analysis, however, that the marginal cost increase, but just that it not decrease faster than the marginal utility of additional forms decreases. Our own argument, which follows shortly, is that the marginal "ascertainment" cost of adding new forms, if positive at all (and whether increasing or decreasing), is always so small as to be well below the utility of permitting greater flexibility in property rights and hence is not a limiting factor.

${ }^{20}$ Merrill \& Smith, supra note 1 , at 39 . 
vides a rationale for limiting the size of menu. The number of forms that the law defines or is prepared to enforce has little bearing on ease of communication. So long as there are clear definitions and labels for the forms most needed, the ability of parties to transact in those forms will not be compromised by the availability of additional forms. Nobody need ever use those additional forms, after all, or even utter their names. Thus, if two transacting persons wish to transfer between themselves an interest in land that has the characteristics of a fee simple, and they know that the term "fee simple" denotes that interest, it is a matter of some irrelevance to them whether or not there also exists another more exotic package of rights designated by the term "fee tail."

This point is illustrated by the example that Merrill and Smith themselves focus on most heavily: a lease for an indefinite term to be determined by occurrence of an event. They point out that, in American doctrine, "[1]eases are limited to four recognized types: the term of years, the periodic tenancy, the tenancy at will, and the tenancy at sufferance."21 A lease "for the duration of the war" or a lease "for life" does not conform to any of those categories. Consequently, the courts, when confronted with an effort to create such a lease, commonly reinterpret it to conform to a standard type that seems reasonably close to what the parties intended, such as a periodic tenancy or a tenancy at will-an amendment that, of course, frustrates the clearly expressed will of the parties.

Should we think of this limitation on leases as serving to reduce "information-processing costs" among parties who lease real estate, as Merrill and Smith's analysis implies? Surely not. It is absurd to think that, if courts were to enforce clearly drawn leases "for the duration of the war" or "for life," the result would be to increase costs for parties seeking to enter into other types of leases. And it is even less credible that leases must be kept to the four conventional categories because adding a fifth category, such as "leases for a period to be determined by occurrence of an event," would generate so much confusion among potential lessees as to outweigh whatever benefits might come from utilizing leasing arrangements of the fifth type.

This problem with the optimal standardization theory is further illustrated by Merrill and Smith's own effort to draw an analogy between property law and language. "The inventory of property rights can be analogized to the lexicon of a language," they assert. ${ }^{22}$ Yet it is unclear why the addition of new terms to a language should reduce the communicative value of those that already exist. Nor does it seem plausible that any language would serve

\footnotetext{
${ }^{21} I d$. at 11.

${ }^{22}$ Id. at 35.
} 
its functions better if the number of words it contains were constrained by public authority to a fixed set. ${ }^{23}$

The third problem with the optimal standardization theory is that property law does not, in fact, offer a fixed set of well-defined standard forms from which parties must choose. Property law tends to regulate the available categories of property rights. It generally leaves the specific content of those rights to be individually specified by the parties who create them, thus allowing substantial room for all the uncertainty and measurement problems that Merrill and Smith see property law as mitigating. Moreover, property law generally does not place absolute limits on the types of property rights that can be created, but rather regulates the forms of notice that must be given of those rights. We will return to offer a closer analysis of these features of property law below ${ }^{24}$ after first offering a different explanation for the law's restrictive regulation of property rights.

Merrill and Smith are correct to focus on the need to assure that the acquirer of rights understands the nature of those rights. The critical consideration lies, however, not in the problem of communication on which those authors concentrate, but instead in the rather different problem of verification.

\section{COORDination, ENForCEMENT, AND Verification}

If two persons are both to have rights in a single asset, they need some means of assuring that they share a common understanding of those rights. Absent such understanding, the parties may mistakenly make inconsistent uses of the asset or underuse the asset. This is the problem of "coordination." Moreover, even if the parties solve the coordination problem, each needs assurance that the other will not opportunistically assert rights that properly belong to the other. This is the problem of "enforcement." The less effectively the parties solve the coordination and enforcement problems, the greater the scope for mistakes or opportunism and hence the less valuable will be the rights involved, for reasons that are apparent: the parties may take costly

\footnotetext{
${ }^{23}$ Merrill and Smith in fact come close to acknowledging this, thus seeming to undercut their own analogy. Id. at 37-38. In discussing their language analogy, Merrill and Smith also introduce an additional argument that is somewhat different from their "optimal standardization" theory. This alternative argument seems based not on limits on the types of property rights that can be created, but on limits on the ways in which those rights can be described. The forms of property rights recognized by the law, they assert, like the words of a language, serve as "building blocks" that can be combined to build larger and more complex structures. They then argue that "a complex of property rights built from a small number of standard building blocks is likely to be easier for third parties to process than functionally equivalent complex property rights for which third parties must figure out the nature of the building blocks." See $i d$. at 37 . This may or may not be true in any given situation. But, if it is, why cannot the parties to a transaction be left to decide for themselves how they are to communicate? Why must the law force them to describe their rights only in terms of a complex combination of a limited set of standard "building blocks"?
}

${ }^{24}$ Section VIII infra. 
private actions to protect their rights; investments in improving and using assets may be discouraged; privately borne risk may increase; and transactions that would otherwise take place may not occur.

Solution of both the coordination and the enforcement problems depends, in turn, on establishing adequate means of verification. To solve the coordination problem, each party needs a means of verifying the other party's understanding of the parties' respective rights. To solve the enforcement problem, a third-party enforcer, such as a judge, needs a method of verifying the parties' understanding of their respective rights. ${ }^{25}$

\section{A. Verification of Contractual Rights}

For persons who deal with each other directly by contract, the contract itself is the principal means of solving both the coordination problem and the enforcement problem. The parties' mutual assent to the contract, testified to by signatures or other conventional means, is the method by which the parties signal to each other that they share a common understanding of their rights-namely, the understanding expressed in the contract. In the language of philosophy and economics, the contract provides a means by which the parties can verify that their respective rights are common knowledge between them. Likewise, the contract provides the evidence that an enforcing court needs to verify the parties' expectations. The law need only supply the general legal rule providing that both parties are bound by the express terms of the contract (supplemented by the default rules of contract law) so long as the contract meets certain conditions of validity. Those conditions are designed to assure that the parties share a common understanding of what they are bound to and that the terms of the contract embody that understanding. Given these general rules governing contract formation, there is little need for the law to limit the substantive terms of contracts, and it generally does not. ${ }^{26}$

\section{B. Verification of Property Rights}

The problem of verification is more difficult in the case of property rights for the reason that two or more holders of property rights in a given asset may not be in privity of contract. Thus, suppose that A sells most of his rights in an asset to $\mathrm{B}$, while retaining some partial rights in the asset for himself. The common understanding between $A$ and $B$, expressed in the contract of sale between them, is that B can transfer all of B's rights in the

\footnotetext{
${ }^{25}$ In the economics literature on contracting, the term "verifiability" is generally used only in the context of enforcement, where opportunism is the problem. We extend it here to the closely related difficulties that are faced in coordination even where opportunism is absent-an issue that would generally be termed one of observability in the economics of contracts.

${ }^{26}$ On the other hand, as pointed out at various points in the text below, and in note 49 infra, default rules of contract law often serve much the same functions as are served by the law's regulation of property rights.
} 
asset, but that B does not have authority to transfer any of A's rights, so that A's rights will be good against any future transferee of B's interest in the asset. Subsequently, B sells his rights in the asset to a third party C. How is $A$ to verify that $C$ shares A's understanding of his rights, rather than, for example, having been misled about those rights by $\mathrm{B}$, who misrepresented A's rights out of mistake or opportunism? And how is C, in turn, to verify the nature of any rights retained by $\mathrm{A}$, rather than, for example, having been misled about the nature of those rights (or even their existence), intentionally or unintentionally, by B? In short, how are both $A$ and $C$ to verify that $C$ was accurately informed about the nature of the rights retained by $A$ ? And, whatever the personal understandings of $A$ and $C$, how is an enforcing court to verify those understandings?

A central problem of property law is to provide mechanisms for solving these verification problems-or, as it is more commonly put, to assure effective notice ${ }^{27}$ To solve these problems, property law employs a variety of verification rules. A verification rule sets out the conditions under which a given right in a given asset will run with the asset. There is a strong relationship between verification rules and the types of property rights-or rather, the forms of ownership-that the law is prepared to recognize. Indeed, the two are inextricably intertwined in any legal regime for property rights. In exploring this relationship between verification rules and forms of ownership, we begin by using the rule of possession as a simple illustration. We then pass on to more refined property rights regimes.

\section{The Rule of Possession}

Of all verification rules, possession is the most primitive and commonplace. ${ }^{28}$ In theory, verification could be based only on possession. Such a strict rule of possession would be simple. It would provide that the party with physical possession of an asset hold complete property rights in the asset and that physical transfer of the asset transfers all of those rights. While nonpossessory rights could be created by contract with the party in possession, those rights would be unenforceable against anyone to whom the current owner transfers possession. Consequently, nonpossessory rights would not be property rights in the sense we use the term here. Rather, they would

\footnotetext{
${ }^{27}$ We are obviously not the first to remark on the important functions served by notice in the law of property. See especially Richard A. Epstein, Notice and Freedom of Contract in the Law of Servitudes, 55 S. Cal. L. Rev. 1353 (1982). See also Carol Rose, What Government Can Do for Property (and Vice Versa), in The Fundamental Interrelationships between Government and Property 209, 213 (Nicholas Mercuro \& Warren Samuels eds. 1999). Our purpose is simply to offer a more systematic analysis of the notice problem and of its relationship to the structure of both property rights and contract rights than appears in the existing literature.

${ }^{28}$ See, for example, Richard Epstein, Possession as the Root of Title, $13 \mathrm{Ga}$. L. Rev. 1221 (1979). Epstein notes, as we echo here, that much of the legal attraction of a rule of possession lies in the ease with which it can be administered and enforced. Id. at 1222-24.
} 
merely be contractual rights, enforceable only against the person who signed the contract.

The advantages of this system are obvious. It is easy to understand, cheap to administer, and generally unambiguous. It is, in fact, reasonably close to the approach taken to most chattels. But the disadvantages of a simple rule of possession are equally clear. It can support only a single form of ownership that encompasses all useful rights in the object-a simple unitary property right. Thus, it precludes a wide range of valuable divided property rights, including leases, servitudes, bailments, security interests, trusts, and future interests. The great utility of divided rights such as these, in which at least one of the rights holders in an asset is not in possession of the asset at any given time, has forced all legal systems to supplement possession with other verification rules. ${ }^{29}$

\section{Verification Rules and Property Rights: An Example}

To illustrate more clearly the relationship between verification rules and property rights, it is helpful to focus on a concrete example. For this purpose, we return to artists' rights, and particularly to the right of integrity. We use this example for a number of reasons. First, it is simple. Second, many different verification rules could quite plausibly be employed for the right, and in fact an unusual variety of rules can actually be found among the different jurisdictions that recognize the right. Third, there remains active debate, not just about the appropriate form and structure for the right, but about the value of recognizing it in any form at all. While we will touch on the merits of that debate later in the essay ${ }^{30}$ the basic issues will immediately be apparent. As a consequence, the right of integrity offers an unusually good illustration of the competing costs and benefits of recognizing property rights, and particularly of the reasons why the law might not make provision for recognizing a property right.

We proceed by examining a series of four stylized property rights regimes that might be applied to an artist's right of integrity. These regimes employ different verification rules and support different sets of property rights. The four verification rules are (1) universal presumption, (2) explicit contracting, (3) labeling, and (4) registration. Each regime has two basic variants, labeled $a$ and $b$, which differ in terms of whether the existence or the nonexistence of a right of integrity serves as the default pattern of rights. As we will see, these four pairs of alternative regimes are not entirely discrete. In important part, the differences among them are matters of degree. This is because the underlying problem of verification is itself a matter of degree.

\footnotetext{
${ }^{29}$ There is also the problem of what constitutes a transfer of possession. If theft does not constitute a valid transfer, for example, then the law must recognize a nonpossessory right in the victim of the theft, thus making a truly pure rule of possession even more unattractive.

${ }^{30}$ See Sections VII $B$ and IXC infra.
} 
Some readers, and particularly Europeans, may object that artists' rights, and especially the right of integrity, are not really property rights but rather "personal" rights or "rights of personality." In our view, the right of integrity is in fact a relatively typical property right, very much like a restrictive covenant on real estate. Those troubled by the example, however, may prefer to think instead of the artist's resale royalty right. Nearly everything said here about the right of integrity (including the debatable value of making provision for the right) applies as well to royalty rights, and we will in fact make explicit reference to that right at various points. Or, for an even more conventional example, one can think of a right, held by an Institute for Historic Preservation, to insist, subject to specified guidelines, that no structural modifications be made to buildings built before $1850 .{ }^{31}$ In the footnotes, we indicate briefly how each of the property regimes we describe here could be employed for a preservation servitude of the latter type.

\section{A. Fixed Rights, No Contracts}

We begin with regimes in which the structure of rights is mandatory and cannot be altered even by contract. Such regimes might take, among others, either of the following two forms:

1a. No Right of Integrity. Any effort by an artist to retain a right of integrity is unenforceable in the sense that an owner ${ }^{32}$ of a work of art must always have full rights over the work, including the right to alter or destroy the work. Even a contract between the artist and the current owner of the work that purports to give the artist the right to prevent that particular owner from altering or destroying the work is unenforceable. ${ }^{33}$

1b. Mandatory Right of Integrity. An artist always retains an unwaivable standard-form ${ }^{34}$ right of integrity whose terms are set by law. Even a contract between the artist and the current owner of the work, in which the artist seeks to waive his right to object to specific alterations by that owner, is unenforceable. ${ }^{35}$

\footnotetext{
${ }^{31}$ The institute might be either a public or a private organization. An example of an analogous private organization is the Nature Conservancy, which (in addition to purchasing land outright) purchases wildlife preservation easements in property throughout the United States.

${ }^{32}$ We use the word "owner" here somewhat casually to mean the person who owns all rights in a work of art other than the artist's right of integrity.

${ }^{33}$ In the Institute for Historic Preservation (IHP) example: Negative rights, held in gross, that prevent modification of buildings are unenforceable even if they are merely contractual.

${ }^{34}$ For the property right to be well defined, the law would have to specify such details as the types of works covered by the right and the types of alterations (reframing? deterioration through neglect?) to which the artist could object.

${ }^{35}$ In the IHP example: The IHP has an inalienable and unwaivable right to prevent modification of any building built before 1850 .
} 
Both of these regimes have the advantage of offering a strong, simple, and low-cost solution to the verification problem. So long as all persons involved simply know the legal rule, there is no room for confusion between artists and owners of artwork as to the rights that each possesses. A judge, likewise, has no difficulty in verifying the legitimate expectations of artists and owners.

Why might the law go so far as to refuse to recognize even a contractual rearrangement of these rights? The reason would presumably be that, owing to mistake or opportunism, the parties' signatures on a contract would not provide adequate verification of the parties' understanding of their rights. In particular, regime $1 a$ might be chosen because of concern that a purchaser of a work of art might not understand the meaning of the rights the artist is retaining. Or regime $1 b$-an inalienable right of integrity - might be chosen because of concern that an artist might not comprehend the nature of the rights he will be (understood as) giving up. In fact, apparently for the latter reason, regime $1 b$ is explicitly the regime that governs the artist's right of integrity in France. ${ }^{36}$ (Regime $1 a$ has apparently not been adopted anywhere, presumably because collectors are thought better able than artists to look out for themselves.) These regimes illustrate, then, that the verification problem arises for contract rights as well as for property rights and that one solution to the verification problem for contract rights, as for property rights, is to limit the types of rights that can be created. ${ }^{37}$

While these two regimes are similar in permitting no flexibility in structuring property rights-a true numerus clausus - they differ in the character of the rights they support, the first providing for a single unitary form of ownership and the second providing for divided property rights. Which of the two might be more efficient depends on at least two factors. The first is the value of permitting the artist to maintain some control over the treatment of his work. The second is the cost of spreading knowledge of the rule among artists and collectors. In the latter respect, rule $1 a$, the simple unitary property right, might seem to have a strong advantage. But that is not necessarily the case. In a society with strong reverence for art and its creators, the natural background expectation of both artists and collectors might be that collectors have no legitimate right to alter or damage serious works of art.

\footnotetext{
${ }^{36}$ In practical effect, this does not mean that an artist cannot consent to acts that would violate his right of integrity, but rather that he cannot bind himself to such a waiver; that is, he cannot enter into an enforceable agreement not to change his mind in the future and seek a judicial remedy for the violation See Federic Poullard-Duhan, Moral Rights in France, through Recent Case Law, 145 Revue Internationale du Droit d'Auteur 126 (1990); Alain Strowel, Droit D'Auteur et Copyright: Divergences et Convergences: Eude de Droit Comparé 497-98 (1993).

${ }^{37}$ See infra note 49.
} 


\section{B. Fixed Rights with Contractual Alterations}

Another approach to the verification problem is to provide for a mandatory property rights regime but to permit individual artists and collectors to alter that pattern of rights as between themselves. Those alterations would be merely contractual and could not bind third-party transferees. Again, we offer two alternative regimes as examples:

2a. Artist's Right Only by Contract. An artist can prevent alteration or destruction of one of her works only if the current owner of the work has explicitly agreed with the artist, by contract, to give the artist that right. Subsequent owners of the work will not be bound unless they too enter into such a contract with the artist. ${ }^{38}$

2b. Artist's Right by Presumption with Contractual Waiver. All works of art are subject to a standard-form right of integrity. The right can be waived by the artist, but a waiver can be granted only to a specific owner of the work for specific alterations and is not transferable by that owner to subsequent owners. ${ }^{39}$

Regime $2 a$ characterized most states in the United States prior to 1990. Regime $2 b$ prevails in Italy. ${ }^{40}$ These two regimes, like regimes $1 a$ and $1 b$, differ from each other in terms of their background (default) property rights. Indeed, regimes $2 a$ and $2 b$ differ, respectively, from regimes $1 a$ and $1 b$ only in permitting deviation by means of contract from the law's initial assignment of rights.

Consider, in this respect, the difference between regimes $2 a$ and $1 a$. Regime $2 a$, unlike regime $1 a$, is not a simple prohibition on an artist's ability to maintain control over the treatment of his work by those who possess it. Rather, regime $2 a$ permits an artist to seek to establish such control by contractual means. By adding the rules of contract law as a social means of verification, greater flexibility in the control of assets is permitted. In fact, with the tools of contract, the artist can construct any particular variation he chooses on the right of integrity-permitting some alterations of his work, for example, and preventing others. Like regime $1 a$, however, regime $2 a$ still does not permit an artist to retain a right of integrity that is a property right in the sense that, once established, that right will bind future transferees of the work.

This does not mean that, under regime $2 a$, an artist has no way to bind successive purchasers of his work not to alter or destroy that work-that is,

\footnotetext{
${ }^{38}$ In the IHP example: The IHP can contract with individual property owners of pre-1850 buildings for a right to prevent modifications.

${ }^{39}$ In the IHP example: The IHP has a right to prevent modifications of any pre-1850 building but can grant specific waivers to individual owners.

${ }^{40}$ See Hansmann \& Santilli, supra note 1, at 129.
} 
to make his right effectively run with the work. Rather, the artist can seek to accomplish that result through a series of contractual commitments. For example, an artist might put in his contract of sale, when he sells a work to the first purchaser, a clause committing the purchaser (1) to neither alter nor destroy the work, and (2) to resell the work only to persons who, prior to completion of the sale, enter into a similar contractual commitment with the artist. ${ }^{41}$ This approach would be awkward, but could be made reasonably effective. The incentive of each subsequent owner of the work to honor the restriction on resale might be enhanced by a provision for substantial liquidated damages (for example, 50 percent of the sale price) in case of breach. To add further to the viability of this approach, the artist might (in the case of a painting, for instance) attach a notice to the back of the work stating the terms of the initial contract. An artist-or a group of artists or an artists' association-might also obtain contractual commitments from galleries and auction houses that deal in their work not to broker resales of the work in which the purchaser does not make the requisite contractual commitment to the artist.

We will term this approach a "contractually structured running right" of integrity. We term it a "contractually structured right" rather than "contract right" to emphasize that what makes the artist's right effective against subsequent purchasers of his work is not a single contract but a system of related contracts. We term it a "running right" to emphasize that, like a true property right, it will (if successful) bind subsequent purchasers of the work. This approach, particularly if pursued by a large number of artists and accompanied by substantial publication and monitoring (for example, through an artists' association), could be quite effective in giving artists the desired degree of continuing control over their works. In fact, just such a contractually structured running right (granting the artist not only the right of integrity but also a resale royalty right of 15 percent on the proceeds of all future sales) was seriously promoted in the United States in the early $1970 \mathrm{~s}^{42}$ and, although never widely adopted, is apparently still employed by some artists. ${ }^{43}$

\footnotetext{
${ }^{41}$ A variant on this approach would be to require each owner of the work, upon resale of the work, to insert terms in her own contract of sale that would commit the purchaser both to respect the artist's right and to impose the same terms by contract on any person to whom he then sells the work-with the terms of all these subsequent contracts to provide explicitly that the artist is to be a third-party beneficiary of the contractual clauses in question with the right of enforcement. The terms might also commit the parties to send copies of all subsequent contracts to a designated gallery representing the artist to simplify enforcement. This approach would work in the civil law countries and in the United States, where contracts can be enforced by third-party beneficiaries, but not in England, where they cannot. In this respect, we note that a legal system's willingness to grant enforcement powers to third-party beneficiaries is also at heart a question of the verification systems it will recognize and consequently involves efficiency concerns of much the sort we explore here.

${ }^{42}$ The contract was drafted and promoted by New York lawyer Robert Projansky in the early 1970s. It is reproduced in John Henry Merryman \& Albert E. Elsen, Law, Ethics, and
} 
We see then that, even if the only accepted set of verification rules for divided rights in an asset are those offered by contract law, it is nevertheless possible to construct a partial right in an asset that will bind subsequent purchasers of other rights in the asset and therefore will effectively have the characteristics of a property right, as we use the latter term here. The parties will, however, generally need to work much harder to accomplish this result than they must where the law permits the enforcement of a conventional legally defined property right. The importance-or unimportance-of this distinction is illustrated by our next set of regimes.

\section{Property Rights by Labeling}

We now turn to rights whose presence or absence is verified by a sign that is attached to, or travels with, the asset itself.

3a. Artist's Right by Labeling. An artist is presumed not to have a right of integrity, but can impose the right upon a work by attaching an appropriate symbol to the work itself (for example, a circled letter " $i$ " after the artist's signature). Any person who subsequently acquires a work bearing that symbol is bound by the right, which can be enforced against him directly by the artist. ${ }^{44}$

3b. Artist's Right by Presumption with Transferable Waiver. ${ }^{45} \mathrm{An}$ artist is presumed to have retained a standard-form right of integrity, and any purchaser of the artist's work is bound by that right, unless the artist has executed a written waiver of the right. The waiver is transferable with the work of art. ${ }^{46}$

While we know of no jurisdiction that employs regime $3 a$ for the right of integrity, such a regime was long used in the United States for the analogous purpose of establishing an author's copyright (by putting the mark "C)" on

the Visual Arts 4-144 (1979). See also Robert E. Duffy, Art Law: Representing Artists, Dealers, and Collectors 282-84 (1977).

${ }^{43}$ See, for example, Martha Buskirk, For Artists' Royalties (interview with Hans Haacke), Art Am., July 1991.

${ }^{44}$ In the IHP example: The IHP can acquire a right to prevent modifications of any pre1850 building, and the right will be enforceable against subsequent owners if the entrance to the building is marked with a historic preservation plaque.

${ }^{45}$ Regime $3 b$ as described here is not the exact dual, or inverse, of regime $3 a$, which would be a system in which a symbol is put on the painting by the artist if he does not choose to retain the right. Thus, if the standard-form waiver were required to be affixed to the back of the work, $3 b$ would be more literally the inverse of $3 a$. But the difference is not very meaningful. One need be less concerned about separation of the label from the work in regime $3 b$ than in regime $3 a$, since with the former but not the latter the current owners of the work have an incentive to make certain the label remains in evidence.

${ }^{46}$ In the IHP example: The IHP has a right to prevent modification of pre-1850 buildings, but may grant a transferable waiver of that right. 
copies of the author's work). ${ }^{47}$ Regime $3 b$ is the one that was adopted in the United States in 1990 and has also been adopted by the United Kingdom. ${ }^{48}$

It is instructive to compare regime $3 a$, which permits an artist to retain a right of integrity that has the form of a "formal" property right, with regime $2 a$, which permits only the creation of a contractually structured running right of integrity. In particular, it is important to see that the practical distinction between the two regimes is, in the end, only one of degree. Affixing the symbol to the work in regime $3 a$ is very much like putting the appropriate clauses in the contract of sale under a contractually structured running right of the type we described above. Both are understood to bind the first purchaser to respect the artist's right. Both are also understood to bind the first purchaser to sell the work to subsequent purchasers subject to that right-in the one case, by putting the appropriate clauses in the contract of sale and in the other by refraining from removing the telltale symbol before selling the work. Both leave room for the first purchaser or subsequent purchasers, either opportunistically or by mistake, to sell the work free of the artist's right-in the case of the contractually structured right, by failing to extract the appropriate contractual commitment, and in regime $3 a$, by removing the symbol.

Thus, regimes $2 a$ and $3 a$ are not sharply distinct. Just how close the two regimes are depends on the detailed rules of interpretation that flesh them out. Suppose, for example, that regime $2 a$ is in effect. Artist A sells a sculpture to collector $B$, insisting that $B$ make the requisite contractual commitments to create a contractually structured running right. B (or some other subsequent purchaser) then sells the work to $C$ without requiring that $C$ in turn undertake the requisite contractual commitments. $C$, however, knows of the contract between $\mathrm{A}$ and $\mathrm{B}$ and knows that $\mathrm{B}$ is clearly in breach of that contract by reselling to $C$ without insisting that $C$ bind himself by a similar contract. If $\mathrm{C}$ subsequently seeks to alter or destroy the sculpture, and $\mathrm{A}$ sues $\mathrm{C}$, will the court dismiss the action, or might it give $A$ a remedy against $C$, perhaps on a theory of unjust enrichment or tortious interference with contract? The more willing the courts are to give A a cause of action in such cases, the closer the contractually based regime $2 a$ is to the "true" property right regime $3 a$.

Conversely, suppose that, under regime $3 a$, artist A sells a sculpture to $\mathrm{B}$ with the symbol affixed, but $B$ removes the symbol before reselling to $C$. And suppose that $\mathrm{C}$ was aware that $\mathrm{B}$ (or some other intermediate owner in the chain of title) had removed the symbol. Would a court then permit $\mathrm{C}$ to interfere with the rights that A had sought to retain (that is, to alter or destroy the work) on the grounds that the requirement for notice in the form of the symbol is a strict one? If so, then of course regime $3 a$ moves closer to regime $2 a$.

\footnotetext{
${ }^{47}$ The United States abandoned this approach by adhering to the Berne Convention, which demands that signatories grant copyright to authors automatically and not make the right dependent on any such labeling.

${ }^{48}$ See Hansmann \& Santilli, supra note 1, at 124-25.
} 
To the extent that regimes $2 a$ and $3 a$ differ in practice, the choice between the two regimes involves a trade-off between the costs and the effectiveness of verification. A contract containing a statement of the artist's rights, and signed by the current owner of the work, is strong evidence that the owner had effective notice of the right. It may well be stronger evidence to this effect than is the existence of a symbol attached to the work, whose precise significance may be unknown to some purchasers or which a purchaser might even overlook. The symbol approach, on the other hand, requires far less effort on the part of the artist to assure that subsequent purchasers will have clear notice of his right. Another consideration in choosing between regimes $2 a$ and $3 a$ is whether the right will be sufficiently valuable and popular to justify the costs of educating artists, galleries, and collectors as to meaning of the symbol (since without such knowledge, the symbol approach may lead to many errors).

We see then that the difference between a legal regime that gives parties the ability to alter their relationships only by contract and a legal regime that also gives parties the ability to alter their relationships by altering property rights is ultimately quantitative rather than qualitative. The rules of contract law and the rules of property law are just two different means of coordinating parties' expectations and giving evidence of those expectations to a third-party enforcer-that is, of permitting both parties and a judge to verify the parties' expectations (or, in more familiar but less precise terms, of providing notice) ${ }^{49}$ Furthermore, at the margin, the two types of rules merge into each other.

And what about the choice between regimes $3 a$ and $3 b$ ? As with regimes $2 a$ and $2 b$, regimes $3 a$ and $3 b$ differ only in the pattern of rights they set as the default. The first regimes of each pair-regimes $2 a$ and $3 a$-require that parties who wish to establish the artist's right take affirmative steps to opt into it, while the second regimes of each pair-regimes $2 b$ and $3 b$-require that parties who do not want the right take similar steps to opt out of it. An important consideration in choosing between the $a$ and the $b$ regimes then

\footnotetext{
${ }^{49}$ It is not surprising, therefore, that our analysis of property rights has parallels in contract theory scholarship. See, in particular, Charles J. Goetz \& Robert E. Scott, The Limits of Expanded Choice: An Analysis of the Interactions between Express and Implied Contract Terms, 73 Cal. L. Rev. 261, 290-91 (1985), which observes that, for reasons of coordinating expectations between parties and permitting third-party verification of those expectations that are similar to those that we focus on here, the law often imposes on parties to a contract a heavy burden in showing that they intended to deviate from the default terms imposed by law or conventional usage. A similar point is made by Ian Ayres \& Robert Gertner, Filling Gaps in Incomplete Contracts: An Economic Theory of Default Rules, 99 Yale L. J. 87, 123 (1989), which emphasizes the role of a strong bias toward particular default rules in contract law as a means of preventing opportunistic conduct by one of the parties (paralleling the opportunistic conduct of the person who seeks to convey more property rights in an asset than he in fact rightfully holds) and which notes that this interpretive bias can become so strong as to fade into mandatory ("immutable") rules. See also Eyal Zamir, The Inverted Hierarchy of Contract Interpretation and Supplementation, 97 Colum. L. Rev. 1710, 1788-1800 (1997); and Eric Rasmusen, Explaining Incomplete Contracts as the Result of Contract-Reading Costs, 1 Advances Econ. Analysis \& Pol'y, No. 1, Article 2 (2001).
} 
is whether the right is likely to have substantial value for a large percentage of the works of art covered by the regime. Another consideration, so far as the labeling regimes $3 a$ and $3 b$ are concerned, is how practical it is to affix a symbol to the relevant works of art or to keep track of a waiver.

In principle, either regime $3 a$ or $3 b$ could support, not just the presence or absence of a single standard-form right of integrity, but alternatively an infinite variety of individually tailored rights regimes. For example, under regime $3 a$, the artist might be permitted to attach to the work itself-for example, to the back of a painting-a statement of the particular terms of the integrity right that he retains. Thus, the artist might require that the work be displayed in a particular type of frame or that the work be maintained or cleaned in particular ways at regular intervals. Or the possibilities could be extended to other types of rights that might interest an artist. For example, an artist might, by such a labeling method, retain the right to have access to the work on reasonable conditions to photograph it or might retain the right to insist that the work be made available for up to 90 days within each 4 years for exhibitions in museums or galleries. ${ }^{50}$ Likewise, under regime $3 b$, partial waivers might be permitted, which would allow the work to be altered in some ways but not others.

Whatever the plausibility of such variable-right labeling regimes for artists' rights, regimes of that character are familiar in other contexts. A common approach is to place the detailed terms of the right not on the label itself, but rather in another document-often a contract-to which the label refers. For example, to indicate the presence of a mortgage on a parcel of land, the ancient Greeks placed on the parcel a heavy stone with a brief inscription; to determine the detailed terms of the mortgage, one had to turn to the contract between the owner and his creditor. ${ }^{51}$ Similarly, modern commercial aircraft that (as is common) are leased or financed subject to a security interest commonly have attached to them a plaque giving notice of the lessor's or financing party's rights; again, the contract must be consulted for details.

\section{Property Rights by Registry}

The obvious difficulty with variable-rights labeling regimes of the type just discussed is the potential for loss or alteration of the label (or the document to which it refers) and the uncertainty of rights that this possibility engenders. Hence, variable-rights regimes often employ verification rules

\footnotetext{
${ }^{50}$ The Projansky contract, discussed in note 42 supra, in fact provides for rights of just these sorts.

${ }^{51}$ Moses I. Finley, Economy and Society in Ancient Greece 63-64 (1982).
} 
based on registries. ${ }^{52}$ Our final hypothetical regimes are therefore of that character.

4a. Property Rights by Registry. A public registry for works of art is established. An artist may register individual works there, and file a notice that the work is subject to a right of integrity. The artist can tailor that right as he chooses, so long as the right remains within the legally specified parameters of a "right of integrity." A purchaser of a work is bound by the terms of the registered right, whether the person has consulted the registry or not. ${ }^{53}$

4b. Artists' Rights by Presumption; Variable Waiver by Registry. A public registry for works of art is established. An artist is presumed to retain a standard-form right of integrity. Partial or complete waivers of the right are valid if registered. ${ }^{54}$

As we have progressed through the four types of regimes, the difference between the dual $a$ and $b$ regimes has become less significant. This is because the importance of the default regime decreases as costs of deviating from that regime decrease. With registry regimes such as $4 a$ and $4 b$, the practical difference between the dual regimes may be unimportant.

Although establishing a registry simply to support the right of integrity might well seem fanciful, registries for works of art in general are not. Such registries are, in principle, relatively easy to construct, and have been seriously proposed as a means of inhibiting theft (which is to say, to provide a verification system to support the nonpossessory property rights of victims of theft). Art registries would also improve substantially the enforceability of the artists' resale royalty rights that are about to extend throughout the European Union. Once an art registry is established to serve other purposes such as these, the cost of extending it to cover the right of integrity would be quite modest. In any event, an important reason why we have used the right of integrity for illustration is precisely because it is debatable whether the value of the right is sufficient to justify the costs of an adequate verification regime.

A registry permits great flexibility in the structure of the rights that can be created. As with labeling regimes, there are two ways in which this can

\footnotetext{
${ }^{52}$ For a thoughtful survey of the law and economics of different forms of land registries, consistent with the analysis offered here, see Benito Arruñada, The Enforcement of Property Rights: Comparative Analysis of Institutions Reducing Transaction Costs in Real Estate (working paper, Univ. Pompeu Fabra, Barcelona 2001).

${ }^{53}$ In the IHP example: The IHP may purchase a right to prevent modification of a given building, and that right will be enforceable against subsequent owners of the building if it is registered in the land registry.

${ }^{54}$ In the IHP example: The IHP has a right to prevent modifications of any pre- 1850 building but can grant a partial or complete waiver of that right that will extend to subsequent owners of the building if the waiver is recorded in the land registry.
} 
be accomplished. One is to provide for registry of the particular terms of the right. The other is to have the holder of the right-in our example, the artist-place in the registry only an indication of the presence of a right, whose terms are contained in a separate nonregistered document (such as the artist's contract of sale with the first purchaser of the work). A conspicuous example of the latter approach is provided by security interests under U.S. law. To be enforceable, a security interest must generally be registered. An effective entry in the registry, however, generally need only identify the debtor, the holder(s) of the security interest, and the burdened property. The detailed terms of the interest, which may include highly individualized and complex covenants, are contained in the security agreement between the owner of the property and the creditor who holds the security interest. To verify the precise terms of the interest, resort must be had to that contract, which, like contracts in general, is itself a reasonably effective verification device, bearing the explicit witness of each holder of partial rights in the asset. ${ }^{55}$

In short, a registry regime such as $4 a$ offers flexibility in the structure of rights, highly reliable verification, and a low cost of establishing rights. On the other side of the ledger, it involves relatively high costs of two types. The first is the cost of establishing and maintaining the registry. The second is the cost imposed on all art purchasers of searching the registry (or, if they choose not to search, of remaining uncertain concerning the scope of their rights).

Cost trade-offs of similar character underlie choices among property regimes in general. We now examine those trade-offs in more general terms.

\section{Choosing among Property Regimes}

A property rights regime assigns to any given type of claim on an asset a verification rule specifying the type of notice that is needed to make that claim enforceable as a property right that runs with the asset. The question in choosing a property rights regime, then, is what type of verification rule to assign to any given type of property right-and, in particular, whether to choose a rule that makes it easy to establish the right.

\section{A. $\quad$ Cost Trade-Offs}

It is helpful to distinguish three categories of costs that, for any given property right, can vary from one verification rule to another.

\footnotetext{
${ }^{55}$ To be sure, the security agreement does not strongly limit the prior creditor's claim on the asset, which can be increased even as against a subsequently filing creditor if the prior filing creditor extends additional credit under a new security agreement. To prevent this, the subsequently filing creditor must obtain, in addition, an explicit commitment from the prior creditor.
} 


\section{User Costs}

First, there are the user costs of establishing the right, by which we mean the costs borne by persons who choose to establish relationships governed by the right. In the case of the right of integrity, these are the additional costs borne by an artist and by those who purchase that artist's works that are incurred when the artist retains a right of integrity. In regime $2 a$, these are the costs of writing and enforcing the series of contracts involved in constructing a contractually structured running right. In regime $4 a$, these are the costs to the artist and to the successive purchasers of his work of entering, maintaining, and checking the requisite entry in the registry.

\section{Nonuser Costs}

Second, there are the costs that a verification rule imposes on persons who seek to acquire or sell assets that are not governed by the right in question. These include the costs of assuring that a proffered asset is not burdened by the right and the costs of bearing the risk that one is mistaken in this respect. ${ }^{56}$ In regime $1 a$, these costs are effectively zero: artists and patrons who do not wish to be governed by an artist's right of integrity need incur no expense to understand their rights. They are assured, with no need for investigation or precaution, that there is no such enforceable right between them. These costs are also zero in regime $1 b$ because nobody can enter into relationships not governed by the artist's right and hence nobody will incur the (effectively infinite) costs of doing so. In regime $4 a$, purchasers of art who do not wish to be governed by a right of integrity, and purchasers of art by an artist who did not retain such a right, must consult a registry to verify their understanding of their rights and hence must incur the cost of that consultation (or bear the costs of remaining uncertain of their rights).

\section{System Costs}

Third, there are general, relatively fixed costs of establishing and maintaining a given verification rule for a particular right. With regime $1 b$, for example, these are the costs of educating the relevant portions of the public about the existence of a mandatory artist's right of integrity. With regime $4 a$, these costs include not just the costs of educating the public, but also the costs of establishing and maintaining a registry.

A choice among alternative verification rules involves a trade-off among these different types of costs. In particular, a verification rule with relatively

\footnotetext{
${ }^{56}$ Note that no feasible set of verification rules is likely to eliminate all errors in coordination and enforcement. The different levels of error costs associated with different verification rules are an important element in the efficiency calculus.
} 
low user costs commonly involves relatively high nonuser costs, or high system costs, or both. Thus, as we move among our alternative artists' rights regimes from $1 a$ to $2 a$ to $3 a$, the costs to an artist and his patrons of establishing a standard-form right of integrity decrease, while the costs borne by artists and patrons who choose not to have such a right increase, as do system costs. Likewise, as we move from $3 a$ to $4 a$, the user costs of establishing a nonstandard (personally tailored) right of integrity decrease, while nonuser costs and system costs both increase. And as we move from the $a$ to the $b$ regimes of each type, user costs decrease and nonuser costs increase, while system costs remain relatively constant.

For simplicity, we will refer to verification rules that have relatively low user costs as "accommodating verification rules" and to those that have relatively high user costs as "unaccommodating verification rules."

\section{B. The Overall Efficiency Calculus}

From an efficiency point of view, the objective in choosing a property rights regime should be to maximize the aggregate value of assets to rights holders less the aggregate user, nonuser, and system costs induced by the rights regime. This means that it is efficient to alter a property rights regime to provide more accommodating verification rules for a particular type of property right only if the resulting reduction in user costs, plus the increase in the aggregate value of assets that results from more extensive use of the right in question, exceeds the concomitant increase in the sum of nonuser costs and system costs.

That cost-benefit test is most likely to be met for rights that have high value to their users and will be used frequently under the new, more accommodating regime. In contrast, it is obviously not worthwhile to adopt an accommodating verification rule, with its concomitant large nonuser and system costs, just to facilitate creation of a right that will have little value or will be infrequently used. It is for this reason that laws facilitating (or mandating) the recognition of artists' rights, such as the right of integrity and resale royalty rights, have been controversial. It may well be, as has often been argued, that the value to an artist of retaining those rights is generally exceeded by an associated diminution in the value of the artist's work to collectors. That is, there may be few cases in which the aggregate value of an artist's work-the value to the artist and collectors combined-is higher when property rights in the work are divided between collectors and the artist rather than held entirely by collectors. ${ }^{57}$ If so, then it is unlikely

\footnotetext{
${ }^{57}$ Since few collectors have an incentive to harm artworks of any significant value, the right of integrity runs the risk of serving in disproportionate degree just for its holdup value, for example, in the case of low-value works that are not easily moved. See note 78 infra. On this and other considerations arguing for and against the utility of the right of integrity, see Hansmann \& Santilli, supra note 1; William M. Landes, What Has the Visual Artist's Rights Act
} 
that the potential gains in those few cases exceed the concomitant increase in nonuser and system costs of an accommodating property rights regime. ${ }^{58}$

\section{Why Restrict the Enforceability of Property Rights?}

We see, then, why the law might, as it does, take a restrictive approach to the enforcement of property rights. Accommodating verification rules comes at a price. Permitting two or more strangers to establish and maintain, with ease, complicated and highly individualized relationships concerning use of a common asset is costly. If the rights in question are likely to be widely used, then it makes sense to set up a regime that has low marginal user costs of establishing the rights, while imposing relatively large, more or less fixed ${ }^{59}$ nonuser and system costs on the rest of society. If, conversely, the rights are not generally of substantial value, it makes more sense to adopt an unaccommodating verification rule that makes the users themselves bear most of the costs of verification.

\section{The Character of the Law's Limitations on Property Rights}

In general, property law does not define and regulate specific well-defined rights. Rather, the law defines and regulates categories of property rights. More particularly, the law demarcates categories of claims on assets-such as servitudes on land, security interests in commercial chattels, or reproduction rights for written works-and establishes for each category a set of

of 1990 Accomplished? $25 \mathrm{~J}$. Cultural Econ. 283 (2001). A resale royalty right, in turn, has the disadvantage of serving as a kind of negative insurance, effectively taxing young and struggling artists while increasing further the rewards that go to the small minority of established artists who are commercially successful. On this and other considerations bearing on the utility of resale royalty rights, see Perloff, supra note 13; and Hansmann \& Santilli, supra note 13.

${ }^{58}$ Moreover, if (as has been common in Europe) the property rights regime takes a mandatory rather than simply an enabling approach to artists' rights, it may impose even greater net social costs by driving down the aggregate value of most works of art.

${ }^{59}$ Not only the system costs, but also the nonuser costs imposed by a rights regime are generally more or less fixed, varying only modestly with the degree to which the right is used. For example, if an accommodating rights regime employing a registry is adopted for a particular type of right, then all persons who wish to acquire an asset of a type potentially burdened by the right must bear the essentially fixed cost of checking the registry if they want to be certain whether the particular asset is so burdened. Of course, the expected cost of not checking the registry, and hence the incentive to check the registry, will increase as the right is more commonly used. But this effect is likely to be pronounced only for large changes in frequency of use. The decision of a single individual to create the right in a given asset will have no discernible effect on nonuser costs. Merrill \& Smith, supra note 1 , at 45,47 , suggests that the decision of an individual to create idiosyncratic property rights will impose external costs on others and that the law must restrict the ability of individuals to create idiosyncratic rights for that reason. But it is, rather, the establishment of an accommodating rights regime that imposes costs on nonusers and not, in general, the decisions of individuals to make use of the rights accommodated by that regime. 
verification rules that determine when a claim within the category is enforceable as a property right (that is, runs with the asset).

There are only relatively few categories of property rights for which the law provides accommodating verification rules. Other types of property rights are-contrary to a literal interpretation of the numerus clausus doctrine-seldom absolutely prohibited and certainly not in the common law. Rather, property rights that fall outside the standard categories are simply governed by highly unaccommodating verification rules that place a heavy burden on the holder of the right to provide notice to third parties.

The pattern of property rights implied by Merrill and Smith's optimal standardization theory-a small fixed set of well-defined standard forms from which all persons must choose-is therefore not the pattern that we observe. To be sure, the law does occasionally mandate a single well-defined standard form for a property right. The artist's right of integrity in France and Italy is an example, as is the artist's resale royalty right in most jurisdictions that specifically provide for it. One reason for this approach is paternalism toward artists. This has nothing to do with the information problems facing thirdparty purchasers that are the focus of the optimal standardization theory. Nor does this kind of paternalism have much to do with the problems of verification we focus on here. ${ }^{60}$

Another reason for mandating a single form does, however, have a strong link to verification rules. Consider, for example, the artist's resale royalty right. As implemented in most European countries, this right is mandatory and has a fixed schedule of rates. Such a right requires no registry, labeling, or other complex verification system of the type that would be required if the right could be waived or if individual artists were free to choose their own royalty rate. Thus, inflexibility of the right reduces substantially the user, nonuser, and system costs of verification.

As this example suggests, there is a great discontinuity between permitting a single form of property right and permitting more than one. Verification is simple and cheap when a single form of property right is mandated for a given type of claim in a given type of asset. As soon as choice is permitted-even if that choice is only between two well-defined alternatives-much more costly verification rules are generally required. On the other hand, a verification rule that is adequate for a choice between even a small number of different property rights will commonly be adequate for a choice among an indefinitely large number of alternatives.

As a result, the property rights for which the law provides relatively accommodating verification rules have a bipolar character. Typically, for any

\footnotetext{
${ }^{60}$ The paternalism is, however, a concern with notice of a sort. The law essentially assumes that no degree of notice to artists is adequate to provide them with the information they need to make an informed decision about the wisdom of retaining the right in question, so the law simply mandates that they retain it, as we observe in discussing rights regime $1 b$ in Section VIA above.
} 
given category of claims on assets, either the law mandates (or, more accurately, creates a strong presumption for) a single form or it provides for an open-ended set of forms that can be individually tailored. The pattern we do not observe is that predicted by the optimal standardization theory: a small number of alternative discrete forms.

Copyright offers a good example of both patterns. Today, the author of a book is assumed to retain a standard-form copyright in the book. A purchaser of a copy of the book obtains not unrestricted property rights in the book, but only a fixed set of partial rights-namely, all rights other than those contained in the author's copyright, the content of which is fixed by law and effectively nonvariable. Thus, the purchaser may read the book or lend or sell his copy to another person, but he may not reproduce the book, other than in specified ways that fall under the legally defined doctrine of "fair use," until a legally mandated term of years has expired. Thus, the law establishes a single-form fixed division of rights in book copies between authors and purchasers. This approach minimizes verification costs for purchasers of written materials: so long as they know the law of copyright, they know just what partial rights they are purchasing when they buy a copy of a book, without need for further investigation (and thus without need for registries or other aids to verification).

The author, on the other hand, is free to redivide her share of the partial rights in her writings - that is, her copyright-in any way she wants and to sell ("license") the subdivided rights piecemeal to an indefinite number of other persons, who may in turn resell and further subdivide those partial rights. Thus, the movie rights may be sold to one person, the rights to publish a German edition to another, and so forth. This great flexibility is presumably because the verification rules developed for transfer of copyrights, which essentially involve tracing a chain of contractual grants back to the author, impose few additional costs when employed for an infinite number of individually tailored forms of partial copyright compared with the case in which they were employed for verification of only two or three fixed forms.

To be sure, it might be argued that the optimal standardization theory applies not to the specific content of particular rights, but rather to categories of property rights. The civil law's numerus clausus, after all, limits only the categories of property rights that can be created and not the content of specific rights within those categories. For example, servitudes on land and security interests in chattels are two of the property rights included in the numerus clausus. Within these categories, there is substantial freedom to tailor the terms of specific rights. Thus, easements of a potentially infinite variety of types can be created within the permitted category of servitudes on land, and chattel mortgages can likewise vary enormously in their specific financial and other terms. But the number of categories is (in theory, at least) fixed. The common law's regulation of property rights, as we have noted, likewise operates at the category level. 
Yet the optimal standardization theory makes little sense when applied at the category level. The "information-processing costs" and "measurement costs" facing someone who is contemplating the purchase of real estate that might be subject to an easement, for example, are not increased by the fact that the law also allows for property rights in other types of assets, such as security interests in personal property or patents in inventions. Consequently, the efficiency of providing accommodating verification rules for one category of property rights is largely unaffected by the number or nature of the other categories of property rights that the law facilitates, and there is no "optimal" number of standard categories of easily established property rights.

The same is true if we just confine ourselves to different categories of property rights in the same type of asset, such as land. The costs to a potential purchaser of a parcel of land of determining whether or not that parcel is burdened by an easement of way are not increased because of the possibility that the land also might be subject to a mortgage. If anything, it is likely to be just the reverse. If the same verification rules are used for easements as for mortgages-say, a requirement that they be recorded in the same land registry-then the costs of determining whether the land is subject to an easement is likely to be much lower if the law has already provided for the possibility of mortgages, since the system costs of creating the registry will already have been incurred and the prospective purchaser will likely search the registry for mortgages in any event and will turn up easements in the course of that search with little or no further effort.

That is not to deny that nonuser costs, which seem to be more or less what Merrill and Smith have in mind by their "information-processing costs" and "measurement costs," may well increase if the law provides accommodating verification rules for additional categories of property rights in a given type of asset. This is especially likely to be true where the different categories are subject to different verification rules. Suppose, for example, that the law makes explicit provision for both mortgages and easements of way in real property. And suppose that the law requires that mortgages be recorded but permits easements of way to be acquired by prescription and to run with the land even if not recorded. Then a prospective purchaser of property will be forced to incur higher costs in assuring the scope of her title than would be necessary if the law permitted only mortgages, since she must not only check the land registry but also examine the property itself to determine if neighboring property owners might have acquired rights of way. But the net benefits of adding easements by prescription to the categories of recognized property rights is not diminished by the fact that the law already recognizes mortgages. Rather, the net benefits are left unaffected or (as suggested above) increased. The question is whether the value of facilitating the creation of easements of way as property rights exceeds the costs of verification that they involve, including physical inspections by prospective purchasers. 
The law's general requirement that easements and similar servitudes "touch and concern" neighboring land is, in fact, a familiar example of the relationship between verification rules and forms of property rights. Servitudes that meet this requirement are much easier to verify by physical inspection of the property and its surroundings, which remain an important component of the verification rules employed for them (given the weaknesses of the recording system). ${ }^{61}$ Moreover, servitudes meeting this requirement are more likely to serve important purposes than those that do not, and hence are more likely to justify the costs imposed by the verification rules.

The rule-found in both the common law and the civil law ${ }^{62}$ - that a bona fide purchaser in good faith without notice takes an asset free of the claims of others is simply a generic statement about the nature and scope of verification rules. The operative question in applying the rule is, of course, What constitutes "notice" for purposes of the type of asset and claim in question? To ask this, in turn, is to ask what is the relevant verification rule that determines when such a claim can be enforced as a property right (that is, against third-party transferees). Must there be actual notice, or is constructive notice enough - and what kind of constructive notice? Conversely, is actual notice sufficient, even if the formalities (for example, registration) generally called for by the verification rule have not been complied with? Is the purchaser on inquiry notice (that is, must he make active efforts to discover the claims of third parties) if the circumstances of the transaction are sufficiently problematic, and, if so, what will suffice to make the circumstances sufficiently problematic?

\section{The Major Classes of Divided Property Rights}

The choice of a property rights regime must be made socially, prior to the point at which persons interact. It is not a choice that can be left to the decisions of individual actors pursuing individual transactions-or, as it might be put, left to the market. This means that there is no invisible hand to assure that the most efficient property rights regime will be adopted.

Moreover, for the reasons explored above, adoption of a legal regime that facilitates the recognition of a new class of property rights will generally involve a shift in wealth toward the users of those rights and away from nonusers of the rights and from society at large (or from whoever bears the

\footnotetext{
${ }^{61}$ It would, of course, be reasonable to use a stricter set of verification rules for servitudes in gross than for servitudes that touch and concern, including a requirement that the former must be recorded to be enforceable against subsequent purchasers of the land. Yet even the latter verification rule would be costly. If coordination costs between owners of land and owners of servitudes in gross are to be kept within bounds, provision must be made for the name and address of the current owner of a servitude to be kept up to date in the land records. Yet accurate updating of that sort would itself be quite costly, particularly under recording systems of the type traditionally used in the United States.

${ }^{62}$ For example, $\$ 2279$ C. civ (French civil code).
} 
system costs for the new rights). Legal reforms that promote new property rights, or abolish old ones, are therefore likely to be influenced strongly by the relative influence of different interest groups.

Finally, a natural tendency toward doctrinal scholasticism among courts and legal scholars adds arbitrariness and rigidity to property law. This tendency seems, for example, the best explanation for the courts' unwillingness, discussed in Section IV, to recognize leases for an indefinite term to be determined by occurrence of some exogenous event. While one could try to rationalize this unaccommodating attitude in terms of the costs and benefits of verification, the effort would be strained.

For all these reasons, one should not expect existing property rights regimes to conform to a high standard of social efficiency. Nonetheless, at a rough overall level, it is reasonable to expect that the efficiency calculus described in Section VII will be reflected in the law of property rights. Both logic and interest will press lawmakers to accommodate forms of property rights with high utility and potentially low costs of verification.

With this in mind, we survey here four of the most prominent classes of divided property rights: security interests, legal entities, intellectual property, and coordinating rights in real and personal property. With respect to each of these classes, we offer a conjecture about why the utility of the rights merits the social cost of the verification rules necessary to support them, and show how the structure of the rights has been influenced by the limits on feasible verification rules.

\section{A. Security Interests}

A security interest is a contingent claim on an asset that permits the holder of the interest to take physical possession of the asset and sell it to a third party upon the nonpayment of a debt. A security interest is a property right in our sense because, to a greater or lesser degree, it is enforceable against subsequent transferees of rights in the asset, including other transferees of security interests.

The ability to grant a security interest has particular value because it permits a debtor to use her asset for two purposes simultaneously-for its use value in production or consumption and as a means of bonding her agreements to repay debts or perform contractual obligations more generally. The difficulty lies in providing notice of an existing security interest to persons who wish to acquire the asset or to establish their own security interest in the asset.

Where, as with most personal property in most societies, possession suffices to verify ownership, security interests in specific assets for the benefit of specific creditors are infeasible. But there is a second-best kind of security interest that remains workable and that is commonly adopted in legal systems everywhere. In effect, the law simply presumes, as a default rule, that all of a person's creditors are granted a security interest in all of the person's assets 
and that those security interests will all have equal priority. Thus, every time a person enters into a contract, she is presumed to grant to her promisee a security interest in all her property as a bond for performance. Failure to perform will result in a money judgment that can be satisfied by levying on any of her assets.

This rule substantially mitigates the notice problem among creditors. Any potential creditor can assume that all of a debtor's assets are burdened with potential claims by all of that person's creditors and that those claims will limit the security interest that the potential creditor can obtain in those assets. To assess the value of the security interest he can obtain in the debtor's assets, the potential creditor must therefore determine the creditor's overall level of debt. But that is all he need do; he need not seek to discover if specific arrangements concerning specific assets have been made with specific creditors. There remains, of course, a problem of debtor opportunism: the debtor may take on subsequent debt that will dilute the value of the earlier creditors' claim on the debtor's assets. But a lien of uncertain and shifting value is still far better than none at all, which is the only feasible alternative without verification rules that are much more refined-and much more costly. ${ }^{63}$

And what about the debtor's ability to sell assets to a third party? The law deals with this by making the creditors' lien a floating lien, from which assets are released upon their sale by the debtor ${ }^{64}$ and to which assets are added upon their acquisition by the debtor. This solution also leaves room for debtor opportunism, since it leaves open the possibility that a debtor facing insolvency will sell important assets and then spend the proceeds. But a fraudulent-conveyance doctrine can avoid some of the worst abuses of this sort, and for the rest, it is a necessary accommodation to the high costs of establishing more refined verification rules.

Where verification rules that are more effective than mere possession can be established at reasonable cost, security interests that grant priorities to specific creditors in specific assets, or in a designated pool of assets, become workable. Thus, in the United States today there is an elaborate system of security interests under Article 9 of the U.C.C. that utilizes public registries, and of course mortgages giving specific creditors prior liens on real estate have long been available owing to the existence of registries for land.

${ }^{63}$ The problem of debtor opportunism in taking on subsequent debt might be dealt with by making the default system of priorities a first-in-time rule rather than a pro rata rule. That this has not been the system chosen perhaps reflects the difficulties of determining the relative dates of claims or perhaps is an accommodation to the fact that foreclosure on a lien may often take place outside of bankruptcy in a proceeding to which other, earlier creditors are not parties.

${ }^{64}$ The reason that general creditors' security interests are property rights, therefore, and not merely contractual rights against the debtor, is not that they bind subsequent transferees of general rights in the assets themselves, but that they bind subsequent (and, for that matter, prior) transferees of similar general creditors' security interests in the debtor's assets. 
Yet registries are not costless systems of verification, and hence the law continues to place restrictions on the kinds of security interests that can be created even if they are registered. Article 9 of the U.C.C. provides an illustration..$^{65}$ In general, Article 9 permits a creditor to take a security interest in virtually all of a debtor's property, including after-acquired property, that has priority over the claims of all other creditors so long as the security interest is appropriately filed. An important exception to this freedom has been made, however, for purchase-money security interests in the debtor's after-acquired property. A vendor who takes such an interest and files it will have a claim prior to that of all other creditors, including prior creditors who were granted a security interest in all after-acquired property and had duly filed that interest. ${ }^{66}$ Why does the law thus limit the debtor's freedom to assign security interests as he wishes? Might not some debtor judge correctly that, in her particular circumstances, it is worthwhile to commit herself not to assign first-priority purchase-money security interests to future vendors?

Indeed, there may well be such cases. But they are likely to be relatively rare. In most situations, it is to the mutual benefit of a debtor and her current creditors to permit the debtor to purchase needed inputs in the future, subject to a purchase-money security interest that is restricted to those inputs. Consequently, by mandating that purchase-money security interests always trump previously filed security interests in after-acquired property, the law imposes only very modest costs. That same rule, however, presumably results in substantial cost savings, since it effectively permits a debtor to assure a vendor costlessly that the debtor has not previously alienated her right to grant the vendor a purchase-money security interest. By virtue of the rule, there is no need for a vendor to search the registries for previously filed security interests in order to verify a debtor's assertions to this effect. Thus, by limiting the types of property rights that can be created even when notice of those rights can be provided through a registry, the law facilitates the formation of other more useful forms of property rights. By this means, the total value of property rights - the value of the rights created less the user-borne and the non-user-borne costs of the verification rules-is increased.

\section{B. Legal Entities}

At its core, organizational law, by which we mean the law establishing legal entities such as partnerships, corporations, and trusts, involves a reorganization of creditors' rights. In this respect, organizational law is property law. In particular, organizational law permits the owners of a business to partition off the assets used in the business into a separate pool, distinct from the owners' personal assets, for purposes of pledging those assets to creditors.

${ }^{65}$ We are indebted to Barry Adler for suggesting this example.

${ }^{66}$ U.C.C. \$ 9-312. 
This property law function of organizational law is most obvious if we consider a business wholly owned by a single entrepreneur. If the entrepreneur operates the business as a sole proprietorship and subsequently becomes insolvent, all of his assets, business as well as personal, will be treated as a single pool in which all of his creditors, both personal and business, have equal priority claims. If, alternatively, he organizes his business as a corporation of which he is the sole shareholder, the pattern of creditors' rights will be quite different.

To begin with, the entrepreneur's personal creditors (creditors with whom the entrepreneur deals in his own name) will have an exclusive claim on his personal assets (assets held in the entrepreneur's own name). This is a concomitant of the familiar doctrine of limited liability. Of greater interest to us here, however, is a second consequence of incorporating the business: business creditors (creditors with whom the entrepreneur deals in the name of the business) will have a prior claim, over personal creditors, on business assets (assets held in the name of the business). We have elsewhere termed this latter rule "affirmative asset partitioning."67 Unlike limited liability, this rule characterizes all modern legal forms of business organization, including partnerships and trusts.

Affirmative asset partitioning creates property rights. The priority it gives business creditors is binding on all subsequent personal creditors of the entrepreneur, whose claim to the business assets will be subordinated to it. This pattern of property rights could not be obtained without organizational law. Even the modern law of security interests is inadequate to the task. ${ }^{68}$ Organizational law produces the result by establishing a default rule to the effect that, when the formalities of establishing a partnership, corporation, or other standard-form legal entity have been complied with, creditors who are dealt with in the name of that entity will be given a prior claim on assets held in the name of the entity.

This rule provides a relatively simple means of verifying the prior claim of business creditors over personal creditors, much as an individual's creditors are given a lien on all the assets owned by that individual, which is one

${ }^{67}$ See Hansmann \& Kraakman, supra note 1, at 417-23. The label was chosen to distinguish it from the "defensive asset partitioning" that is represented by limited liability and related rules favoring the claims of personal creditors on personal assets.

${ }^{68}$ The problem, in essence, involves creating a particular type of floating lien over all of the organization's assets. The lien must float in three respects: with respect to subsequently acquired assets, with respect to subsequently contracted debt to already existing creditors, and with respect to subsequently contracted debt to new creditors. Article 9 of the U.C.C. will permit a lien to float in the first two respects, but not the third: to add a new creditor to the group of secured creditors requires a new filing under Article 9 that lists the new creditor by name. Moreover, the modern law of secured interests also will not permit creation of the "liquidation protection" shield that organizational law permits, but rather only simple priority of claims. Id. 
reason that legal entities are called juridical "persons." ${ }^{.69}$ At the same time, a verification rule that depends on ownership by fictional legal persons has substantial limitations. One of these is the difficulty of policing the boundary between assets that belong to the entity, and are subject to the business creditors' prior claim, and those that are the personal property of the organization's owners. The owners of a business firm often have an incentive, if the business approaches insolvency, to distribute business assets to themselves and thus eliminate the business creditors' prior claim on those assets.

To deal with this problem, organizational law places restrictions on both the form and conduct of firms formed as legal entities. This is evidently one reason why the form originally established for business corporations was initially extremely rigid and adapted to large but not small firms at the turn of the twentieth century. The larger the firm, the easier it is to segregate the assets of the entity from those of its owners. In addition, the importance of separating the assets of the firm for notice purposes explains the strong focus on legal capital rules in early business corporation law. More recently, advances in accounting procedures, corporate law, and monitoring by private credit-reporting services have reduced the potential for opportunistic transfers of assets across entity boundaries. The law has responded to these lower costs of using entity ownership as a verification rule by continuously relaxing the restrictions on the attributes that an entity must have in order for it to serve as a means of designating security interests in pools of assets.

\section{Coordinating Rights in Real and Personal Property}

The law's provision for servitudes in land (which in the common law has traditionally been fragmented into the separate rules for easements, real covenants, and equitable servitudes) makes it much simpler to establish partial rights in real property than in personal property. Part of the reason for this is that the registries developed for verifying ownership of land are available to record these other interests as well, hence avoiding many of the additional system and nonuser costs that effective verification of these rights would otherwise require.

Another reason, however, is that the spatial fixity of individual parcels of real property causes the value of those parcels to be necessarily dependent on the uses made of neighboring parcels. Without the ability to create servitudes that run with both the burdened and the benefited property, owners of neighboring parcels would be forced to recontract whenever one of the parcels changed hands, with all the potential for inefficient holdup that such recontracting would involve.

Moveable property, by virtue of its defining characteristic, generally does not expose its owners to these problems in coordinating uses. But that is not

${ }^{69}$ See Hansmann \& Kraakman, supra note 1, at 417-23. 
always the case. For example, the strongest arguments for recognizing the artists' rights we have discussed above, the right of integrity and resale royalty rights, are based on the need for coordination. The value of one work by an artist generally depends heavily on the quantity and quality of the artist's other works. A painting by Picasso has value, not just (or even primarily) because of its individual qualities, but also because of its association with the artist's entire oeuvre. The destruction or alteration of individual works can therefore damage the artist's overall reputation and thus decrease the value of the artist's other works as well. Hence, there is some reason to permit an artist to serve as the guardian for the value of his work as a whole by letting him retain a right of integrity. Likewise, as the artist produces new works of quality, the value of his preexisting works increases. A resale royalty right permits an artist to capture part of that value and hence can provide the artist with more efficient incentives for continued production. ${ }^{70}$ That said, these coordination benefits may still be insufficient to justify the costs of accommodating the rights.

\section{Intellectual Property}

We have said that the typical effect of adopting a verification system to facilitate creation of a partial property right is to lower costs to users of that right while increasing both system costs and costs borne by nonusers of the right. Legal rules providing for recognition of intellectual property differ from this pattern. In effect, those rules of law increase costs of all three types: not just nonuser and system costs, but user costs as well.

Consider copyright as an example. Copyright law, as noted earlier, permits the creation of divided property rights in the sense that it allows the right to copy a book (or other publication) to be separated from the right to possess a physical copy of the book and to use that copy for all purposes except for making further copies. But copyright law was not necessary to permit the owner of a copy of a book to sell the right to copy the book while retaining the rights to possess the book and make other uses of it. Absent copyright law, the owner of a book could give to someone else the ability to copy the book simply by letting that person borrow the book long enough to copy it. A would-be copier would have no difficulty verifying that the owner had the right to permit copying; all owners of copies of the book would have that right. With the introduction of copyright law, however, it becomes more difficult for a would-be copier to verify that the owner of a book could grant the right to copy it. Mere possession is no longer enough; documentation that the owner has the copyright must also be checked.

\footnotetext{
${ }^{70}$ Perhaps more importantly, the resale royalty right may also serve the related purpose, for a young artist, of providing a credible signal to purchasers of his work that he has the will and the capacity to continue to produce strong work in the future. See Hansmann \& Santilli, supra note 13.
} 
In short, after the introduction of copyright, users of the right to copy bear higher costs of transactions in rights to copy. Moreover, system costs also increase with the introduction of copyright. And nonuser costs likewise increase, at least mildly, since persons who have no interest in making copies will often still have an interest in knowing whether the price they are paying for written material includes the right to copy it.

But the reason for copyright law, of course, is not to reduce the costs to users of the right to copy, but almost the reverse: to create an artificial monopoly in that right in order to encourage the creation of new texts. If copyright is efficient, it is because the value of those new texts exceeds the increase in user, nonuser, and system costs that copyright engenders. ${ }^{71}$

\section{Other Definitions of Property Rights}

We have taken as the defining characteristic of a property right in an asset the ability of the rights holder to enforce that right against third-party transferees of other rights in the asset. Of course, there are alternative definitions. We examine three of those alternatives here. Each of those alternative definitions captures an important dimension of the meaning of the term "property" as that word is sometimes used in ordinary language and in the law. And each has its advantages for particular purposes. We believe that our own definition of a property right, however, is by far the most useful in understanding the law's conspicuously restrictive approach to the types of property rights it will enforce.

\section{A. Rights Good against All the World}

First, we consider the conception of property that Merrill and Smith emphasize in a series of recent articles. Under their view, the distinguishing feature of a property right is that it is an in rem right that is "good against all the world" in that it permits its holder to exclude all other persons from using the asset in question. ${ }^{72}$ The advantage of such a right, Merrill and Smith emphasize, is that it gives an owner discretion to assign use rights in the asset. By contrast, contract rights are more limited in this view. They bind

\footnotetext{
${ }^{71}$ There is strong reason to believe that the extremely long duration now accorded to copyright is inefficient, and there is even room for debate about whether legal accommodation of copyright in any form is efficient. See, for example, Stephen Breyer, The Uneasy Case for Copyright: A Study of Copyright in Books, Photocopies and Computer Programs, 84 Harv. L. Rev. 281 (1970).

${ }^{72}$ Thomas W. Merrill \& Henry E. Smith, The Property/Contract Interface, 101 Colum. L. Rev. 773, 780, 783-89 (2001). See also Merrill \& Smith, supra note 1, at 32; Thomas W. Merrill \& Henry E. Smith, What Happened to Property in Law and Economics? 111 Yale L. J. 357 (2001).
} 
only small numbers of determinate individuals, and they serve primarily to regulate, or "govern," the use of an asset. ${ }^{73}$

This definition of a property right does not, however, distinguish between contract rights and property rights as the law treats them. In general, contract rights, like property rights, are "good against all the world" inasmuch as any third party who intentionally interferes with a contractual right commonly faces liability for tortious conduct to the holder of the right. ${ }^{74}$

Likewise, this definition of a property right does not appear helpful in explaining the law's limitations on property rights. We can return to the artist's right of integrity as an illustration. Consider two alternative regimes, both of which recognize an artist's right of integrity that runs with the work of art. In regime $X$, the right is enforceable only against the current owner of the work. In regime $\mathrm{Y}$, the right is also understood to give the artist a cause of action, not only against the current owner of the work, but also against any third party who intentionally damages the work. Under the definition we are working with here, the artist has a property right in the work under both regimes $\mathrm{X}$ and $\mathrm{Y}$. Under the Merrill and Smith definition, in contrast, the artist would presumably be considered to have a property right in the work only under regime Y.

We see advantages and disadvantages of both regimes $\mathrm{X}$ and $\mathrm{Y}$. Either would be a sensible means of implementing a right of integrity. But no matter which of these two regimes we consider, the policy question of whether to permit the right to run with the work of art remains more or less unaffected: our extended discussion of the costs and benefits of alternative verification rules for a right of integrity applies more or less equally to both regimes $\mathbf{X}$ and Y. And that policy question, we believe, is the important one in understanding the pattern of divided rights for which the law makes provision. Drawing strong distinctions between regimes such as $\mathrm{X}$ and $\mathrm{Y}$ does not seem to offer important insight in this regard.

The problem here is that the "good against all the world" definition of a property right runs tort and contract together. More precisely, it runs together tortious invasions of the right with efforts to acquire the right by voluntary transfer. Our own definition of a property right, as a right that runs with the asset, focuses on voluntary transfers. In contrast, the "good against all the world" definition, at least as explicated by Merrill and Smith, focuses heavily on tortious interference. But there seems little reason why the structure of property rights need be designed with an eye toward potential tortfeasors.

In general, unless a person wishes to purchase an asset, he has no need

${ }^{73}$ The governance aspect of property rights is discussed at length in Henry E. Smith, Exclusion versus Governance: Two Strategies for Delineating Property Rights, in this issue, at S453.

${ }^{74}$ Restatement (Second) of Torts $\S 766 \mathrm{~B}$. To be sure, negligent, as opposed to intentional, interference with contractual rights will generally not lead to liability, id. at $\S 766 \mathrm{C}$, in contrast to the situation with interests in land. But that distinction does not alter the basic issue. 
to investigate the way in which property rights in the asset are divided. If he wishes to buy rights in the asset, he must learn who currently owns those rights. But in all other circumstances, third parties need to know only one thing to show respect for a stable set of property rights: that the asset and all of its attendant use rights belong to other persons and not to them. Thus, if a person is to avoid trespassing on land, it is sufficient for that person to know that she owns no rights in the land. It is a matter of some irrelevance whether or not rights in the land are all held by a single individual or, alternatively, have been carved up among various persons to include a fee tail, a joint tenancy, an easement, a lease, and/or a mortgage. Likewise, the problem of potential tortfeasors has little bearing on whether or not the law recognizes, say, the fee tail or a lease that will terminate on the occurrence of a specified event.

To be sure, one might reinterpret the "good against all the world" criterion to omit concern with tortfeasors and to mean, rather, good against any person who seeks to acquire the right by voluntary transfer from the holder of other rights in the asset, and who is on adequate notice, under the relevant verification rules for that class of rights, that the right in question does not belong to the person who is offering to transfer it. Then the definition becomes equivalent to that which we are offering here, and we have no objection to it.

\section{B. Alienable Rights}

A second possible defining feature of property rights is that they are alienable to third parties. But this attribute is also not a critical factor in understanding the patterns we observe in the law's recognition of divided rights. In general, whether or not a right is alienable has little correlation with those patterns, and logic does not suggest that it should have.

A good example, again, is afforded by artists' rights. As we have noted, in France the right of integrity is inalienable, and in 2001 the European Union as a whole adopted a directive mandating an inalienable resale royalty right in all member states. Among the various arguments in favor of inalienability is the ease of verifying the right. (With inalienability, a prospective purchaser of a work of art knows with certainty that the right exists and who holds it.) Thus, inalienability can serve to support the feature that we consider key: the running of the burden. But, whether inalienability is adopted for this or other reasons, the law's restrictions on the enforceability of property rights do not seem to be clarified greatly by distinguishing strongly between inalienable and alienable rights.

This is not to deny that some of the same problems of coordination and enforcement-and hence of verification-that arise with the running of the burden of a claim on an asset also arise when a claim, including a claim against a given person and not just a claim on an asset, is transferable. This is evident in the assignment of contractual rights. If $\mathrm{A}$ makes a promise to 
$B$, and $B$ then seeks to transfer the benefit of that promise to $C$, some means is needed by which $A$ and $C$, who are not in privity of contract, can verify that they have a common understanding of the terms of the claim.

In such situations, however, the original contract between A and B can generally serve as an adequate means of verification, since the contract itself can be transferred from B to C (and in turn to others) as evidence of the nature of the claim, and possession of the document (perhaps with appropriate endorsements) can serve as evidence of the rightful claim holder. This means that there is no particular reason to regulate the types of contractual claims that can be made transferable. General rules of contractual interpretation suffice for verification, supplemented in some instances by specialized rules (such as those governing negotiable instruments) to facilitate transferability for the most commonly traded claims. Larger problems of verification, analogous to those created by partial claims on assets, can be created by efforts to make only a partial assignment of a contractual claim. The law generally deals with these problems, however, not by restricting the kinds of partial assignments that can be made, but rather by providing (in appropriate situations) for enforcement by a holder of a partial assignment only if all other promisees are joined in the suit. ${ }^{75}$

A special class of assignable rights are rights that are tied to assets and run with those assets from one owner to the next. A simple example is an automobile warranty that is good for the first 50,000 miles, regardless of whether the current owner was the initial purchaser. In comparison with burdens that run with assets, benefits that run with assets create more modest problems of verification, for reasons similar to those that apply to assignable contractual rights in general. The seller of the asset has every incentive to disclose the existence of the benefit. Moreover, the existence of the right can often be verified with relative ease by a document that can be transferred with the asset, and in case of doubt the purchaser of the asset can verify the benefit by directly contacting the person holding the burden. Consequently, there has been less occasion for property law to develop special verification rules governing particular classes of benefits that run with assets. ${ }^{76}$

\section{Property Rights and Property Rules}

A third potential definition of property rights is that they are rights that are protected by a "property rule," that is, rights that can be specifically

\footnotetext{
${ }^{75}$ See Restatement (Second) of Contracts $\$ 326$ (1981).

${ }^{76}$ The law of legal entities might be considered an exception. That body of law-and most conspicuously the law of business corporations-provides for the benefits and burdens of a group of contracts to be transferred as a group to new owners of the firm, together with ownership of the other assets of the firm.

${ }^{n}$ The reference, of course, is to Guido Calabresi \& A. Douglas Melamed, Property Rules, Liability Rules, and Inalienability: One View of the Cathedral, 85 Harv. L. Rev. 1089 (1972).
} 
enforced. Yet this characteristic seems to bear only an incidental relationship to the question at issue here, namely, the law's conservative approach to recognizing property rights.

To begin with, contract rights can frequently be specifically enforced. The common law, to be sure, confines specific performance to particular circumstances, but the civil law is (at least nominally) less restrictive, and it is the civil law that is most self-conscious about restricting the recognizable forms of property rights.

There is also no necessary connection between the feature that we take here to define a property right in an asset-namely, the running of the burden-and the remedy of specific performance. Again, consider our running example: the artist's right of integrity. The law could provide that this right is enforceable by injunction or only by damages. There are arguments for either approach. In favor of specific performance, on the one hand, is the relative difficulty for a third party such as a court to assess appropriate damages. In favor of a damages-only remedy, on the other hand, is the fact that the right of integrity is most likely to be of serious importance in situations that involve site-specific art, where a specific performance remedy can give an artist enormous holdup power. ${ }^{78}$

\section{Verifiability and Specific Performance in Contract}

Although property rights need not be protected by property rules, they commonly are. In contrast, specific performance is a disfavored remedy for contract rights. The problems of verifiability that underlie the law's conservative approach to property rights help explain why this is so.

Why might a promisor breach an executory contract? One possible reason is that the promisor has, out of mistake or opportunism, made a conflicting promise to another promisee. Promisees concerned about facing nonperformance for such a reason might therefore, if the law would permit it, insist on contractual terms giving them the right to specific performance.

But then what is to be done if, for similar reasons of mistake or opportunism, a promisor makes conflicting promises to two different promisees and, moreover, promises each of them specific performance? Of necessity, only one of the two parties can get the performance and the other must settle for damages. The presence of the specific performance clauses, moreover, will be of little help to the law in deciding which of the two parties gets the promised performance. In short, the two parties will be in the same position

\footnotetext{
${ }^{78}$ In fact, the most important and difficult early case involving application of the right of integrity under the 1990 U.S. legislation, Carter v. Helmsley-Spear, Inc., 71 F.3d 77 (1995), involved sculptures commissioned and designed specifically for the lobby of a commercial building, which was subsequently sold to another owner who wished to remove the artwork over the artists' protests.
} 
they would have been in had they not extracted the promises of specific performance.

The result is that permitting parties to contract for specific performance would run the risk of creating a fruitless arms race. Clauses providing for specific performance would become routine in contracts, since failure to insist on such a clause might leave a party disadvantaged relative to parties with conflicting claims who extract the clause. Yet, if all contracts contain a specific performance clause, contracting parties in general end up no more secure than they were in the absence of those clauses.

The underlying problem is that a promisee cannot easily verify that no previous promisee has already been given a right of specific performance, nor can a promisee assure that notice of his own right of specific performance will be given to future promisees. If there were a registry of some sort for contractual rights of specific performance, the problem might not arise. ${ }^{79}$ In fact, where specific performance is a critical feature of a contract-as with security interests in specific assets-a registry or some other strong means of verification (such as possession of the asset by the creditor) is generally employed.

In short, the problem with granting rights of specific performance is much like the problem, discussed earlier, of granting security interests in personal property when possession is the principal means of verification. The only solution is to treat everyone alike. For security interests, that means that all contracting parties get a shared right to foreclose on all of the promisor's property. For contractual claims, it means that no promisee gets the right to specific performance, but rather that all get only a right to damages, with an award of specific performance limited to particular circumstances as adjudged by a court ex post. ${ }^{80}$

Where property rights are concerned, this problem of conflicting claims is much reduced owing to the existence of verification rules designed to

\footnotetext{
${ }^{79}$ See, in this connection, Barry E. Adler, Financial and Political Theories of American Corporate Bankruptcy, 45 Stan. L. Rev. 311, 336-39 (1993), and Barry Adler, Secured Credit Contracts, 3 The New Palgrave Dictionary of Economics and the Law 405-10 (Peter Newman ed. 1998), which recommend a partial expansion of the contractual commitments that can be filed and enforced as property rights to include a commitment by a debtor to a given creditor not to incur additional debt, either secured or unsecured, to other creditors.

${ }^{80}$ Another important-arguably much more important-reason for the law's resistance to granting a right of specific performance for contractual obligations in general is that they would create excessive risk for all parties. Generally, a party fails to perform a contract not because the same performance has been given to another, but because for other reasons the costs of performance have risen unexpectedly to the point where the costs of performance to the promisor are less than the benefits to the promisee. If the promisee had a right to specific performance, he could often hold up the promisor for an amount far in excess of the value of the promised performance as the price of waiving the right to performance. The result would be that all contracts would become pure gambles on the possibility of an unexpected increase in the cost of performance, inefficiently creating private risk for both contracting parties where there is no social risk and leading well-advised promisors to insist on contractual waiver of the right.
} 
assure notice of the rights to third parties. If party $A$ holds property rights in an asset otherwise owned by party $B$, it is unlikely that B will make commitments concerning the asset to a third party $\mathrm{C}$ that are inconsistent with A's rights, since A's property right will have the benefit of verification rules that put $C$ on notice of $A$ 's rights. And if $C$ accepts such inconsistent commitments from $B$ anyway, the same verification rules will generally resolve the conflict between $A$ and $C$ in favor of $A$. Thus, the criteria that lead to the conclusion that $\mathrm{A}$ has a valid property right also support the conclusion that A should be given specific performance. This contrasts with what we just observed about contract rights: just because a person is found to have a perfectly valid contractual claim does not imply that granting specific performance is an appropriate remedy even if it is feasible. In short, the verification rules necessary to accommodate property rights efficiently also provide support for a remedy of specific performance.

\section{What Is aN Asset?}

In exploring the ability of two or more persons to hold divided rights in a single asset, we have, to this point, taken for granted the notion that there exist identifiable "assets" in which one can obtain full (undivided) property rights. It remains to ask how the law determines what constitutes a single "asset" for the purposes of establishing property rights.

The latter question, however, is essentially the same as the one we have been addressing. To say that two persons hold divided rights in the same asset is little different from saying that the two persons own undivided rights in distinct assets.

Suppose, for example, that A, who owns an acre of land in fee simple, divides the land into two adjoining half-acre parcels and sells one of the parcels in fee simple to B. Do A and B now each have undivided ownership of distinct assets? Or do they have divided ownership rights in a single asset, the given acre of land? The law and ordinary language both generally conceptualize the situation in the former fashion. But, as our discussion in Section IX suggests, it could equally well be viewed the other way. The two parcels are, after all, irrevocably adjoining, and the uses made of one will commonly affect, to a greater or lesser degree, the value of the other.

Now suppose that A, instead of conveying to B the exclusive rights to half an acre, conveys to $B$ the exclusive rights to use the full acre on Saturdays and Sundays, keeping for $A$ the rights to use the land on Monday through Friday. Do A and B now own divided rights in a single asset, namely the acre of land? Or do A and B each own full rights in separate assets, the land on weekdays and the land on weekends, respectively?

The question for the law is the same in either case: what are the conveyable boundaries of property? And this question, as we have argued, reduces to yet another question: what are the verifiable boundaries of property? A simple 
labeling system (for example, fences) is adequate to support division of property rights in land along physical boundaries, at least if backed up by some nuisance law to set the default rules concerning conflicting uses of adjoining parcels. Division in terms of continuous intervals of time (for example, leases, life estates) requires a registry for clear verifiability if the intervals are to be of long duration. It requires as well some more elaborate default rules as to the responsibilities of the interval owners to each other. (These latter rules, like nuisance rules for adjoining parcels, are part of the default definition of the boundaries between the rights belonging to one party and those belonging to the other.)

Once a registry is in place, moving from continuous intervals to time shares (repeating intervals), as in our weekday-weekend rights example above, involves only modest increases in the system costs and the nonuser costs of verification, which consists mostly of the system costs of establishing yet more elaborate default rules concerning coordination between interval owners. The fact that U.S. law did not offer explicit recognition of time shares in real estate until relatively recently, when a number of states adopted legislation to that effect, presumably reflected low demand for the form rather than high costs of establishing adequate verification rules. ${ }^{81}$

\section{Ambiguity Concerning Recognizable Property Rights}

Although time shares in real estate are now generally well recognized in U.S. law, time shares in personal property are not. It therefore remains problematic whether, for example, A could sell to B the weekend rights in A's heirloom watch, while retaining the weekday rights for himself, and succeed in giving $B$ a property right, that is, a right enforceable against subsequent transferees of A's interest in the watch. That is not to say that it is absolutely clear under U.S. law that A could not give B a weekend property right in the watch. ${ }^{82}$ Rather, it presumably remains open to a court to decide that, in a particular case, a third-party purchaser of A's interest in the watch had sufficient notice of B's interest to bind him to respect B's right. Or, better put, a court might find that there was sufficient evidence that both $A$ and $C$ shared the expectation that $C$ would respect A's right.

This is perfectly sensible. There is no particular reason to have a true numerus clausus in the sense of a formal doctrine that explicitly limits property rights to a small well-defined set and requires that all other rights be

\footnotetext{
${ }^{81}$ Merrill \& Smith, supra note 1, at 34, suggests that the law restricts definitions of property rights with respect to "legal dimensions" of assets, which are more difficult for acquirers to "measure" than are "physical attributes." We feel it more accurate to say that the law is concerned with the physical dimensions of assets that are difficult for all parties concerned to verify.

${ }^{82}$ See, for example, David R. Dubord, Time-Share Condominiums: Property's Fourth Dimension, 32 Me. L. Rev. 181, 211-12 (1980).
} 
based on explicit contracts. If, even without benefit of specific affirmative legislation, the relevant parties can coordinate their own expectations to the effect that a given right will run with an asset and can signal those expectations to a court with sufficient clarity, a refusal to enforce the right may simply sanction opportunism and frustrate the parties' original intentions, with no compensating advantage in reducing either system costs or costs borne by nonusers of the right.

It is not surprising, then, that the civil law's numerus clausus doctrine does not have its roots in concerns about the verifiability of claims on assets. Rather, the doctrine was born of the French Revolution, when divided property rights came to be associated with feudal social relations, leading to the conclusion that they must be closely regulated and restricted. After that, it evidently took on a strong life of its own as an abstract doctrine, perhaps because it was well suited to appeal to the scholastic tendencies of legal scholarship. ${ }^{83}$

For all these reasons, the civil law's numerus clausus doctrine today seems highly formalistic, and strict adherence to that doctrine seems counterproductive. It is not surprising, therefore, that there is reason for skepticism as to just how closely civil law jurisdictions adhere to a strict numerus clausus in practice.

For similar reasons, it is understandable that the common law has no formal doctrine equivalent to the civil law's numerus clausus and accompanying unitary theory of property rights. The occasional judicial pronouncements to the contrary frequently have the appearance of makeweight efforts to bolster holdings that are at bottom motivated by narrower considerations of policy. For example, the supposed doctrine that U.S. law will not permit creation of a servitude on a chattel has been invoked most conspicuously in cases involving manufacturers' efforts to impose restrictions on the use of their products, such as resale price maintenance. The courts' rejection of these efforts was evidently motivated by considerations of competition policy that had nothing to do with the problems of notice that generally lie behind the law's unaccommodating approach to divided property rights. ${ }^{84}$ Indeed, the restrictive covenants in these cases imposed few problems of notice, and their rejection on that ground would be hard to justify.

\section{Fragmentation and the Anticommons}

When rights in a single asset are fragmented among two or more different persons, there arises what Frank Michelman and Michael Heller have labeled the "problem of the anticommons," that is, the possibility that transaction costs and holdout problems will become so large as to frustrate otherwise

\footnotetext{
${ }^{83}$ See Hansmann \& Mattei, supra note 1.

${ }^{84}$ See Chaffee, supra note 12.
} 
efficient uses of property. ${ }^{85}$ This anticommons problem has sometimes been invoked to explain why the law accommodates only a restricted set of divided property rights. ${ }^{86}$

The anticommons problem potentially infects nearly all forms of divided property rights and reduces the value of creating partial rights in general. It therefore reduces the net utility of any type of partial right and hence weighs negatively in the cost-benefit analysis described above for determining whether (or rather, to what degree) it is worthwhile for the law to accommodate any particular right. Consequently, the anticommons problem is a reason for the law to accommodate a smaller set of divided property rights than it otherwise would, since the value of the divided rights must exceed not only the three types of costs we have described above, but also the costs associated with anticommons problems.

But, as Merrill and Smith observe, ${ }^{87}$ the anticommons problem does not seem to weigh heavily in determining the particular forms of partial property rights that the law accommodates. Most of the easily created forms of divided property rights limit the types of interests that can be created in an asset, rather than the number of rights holders, and hence can be used to fragment ownership widely. The law's approach is generally not to prevent such fragmentation, but rather to facilitate its elimination when it gets out of hand. This is accomplished through a broad range of familiar doctrines, ${ }^{88}$ including rights to partition cotenancies, rules of desuetude for servitudes, eminent domain, judicial power to dissolve legal entities, and statutory limitations on the lifetime of intellectual property rights. ${ }^{89}$

One reason for this ex post approach to the anticommons problem is that it is difficult to restrict the forms of divided property rights in a way that will prevent fragmentation. Another reason is that excessive fragmentation often arises out of mistake or changed circumstances. It is generally not in the interest of property owners to fragment their rights inefficiently since they will bear the costs of that fragmentation. ${ }^{90}$ Consequently, the most serious

${ }^{85}$ Frank I. Michelman, Ethics, Economics and the Law of Property, in NOMOS XXIV: Ethics, Economics, and the Law 3 (1982); and Michael A. Heller, The Tragedy of the Anticommons: Property in the Transition from Marx to Markets, 111 Harv. L. Rev. 621 (1998).

${ }^{86}$ Bernard Rudden, supra note 1, at 259; and Michael A. Heller, The Boundaries of Private Property, 108 Yale L. J. 1163, 1176-82 (1999).

${ }^{87}$ Merrill \& Smith, supra note 1, at 51-54.

${ }^{88}$ Heller, supra note 1 , offers an extensive and thoughtful survey of these doctrines.

${ }^{89}$ Some of these doctrines might be interpreted as limitations on the types of rights that can be created. But those limitations generally go to the lifetime rather than the character of the right-as with the rule that agreements not to partition a cotenancy are unenforceable if they are of unreasonable duration or the limited lifetime of patents.

${ }^{90}$ An exception involves what we might term "retransfer externalities." After an initial division of property rights in an asset, the holder of one of the partial rights does not bear the full anticommons-type costs of further subdivision of that right, since those costs will in part fall on other holders of the previously divided partial rights in the asset. In an earlier version of this essay, we laid strong emphasis on these and related retransfer externalities. But we now 
anticommons problems seem to arise when a division of rights whose expected value was initially positive is rendered inefficient by time or changed circumstance. To prevent these problems by prohibiting division of rights ex ante is to throw out the baby with the bath water.

Contractual claims on an asset can also become so fragmented that they create severe anticommons problems. But, precisely because contract rights do not run with the asset, anticommons problems of a contractual nature can be eliminated by the simple expedient of selling the asset, hence liquidating all the conflicting claims on it. Thus contract law, like property law, takes an ex post approach to the anticommons problem.

The verification problems created by divided property rights would be present even if the anticommons problem were nonexistent. And it is those verification problems, and not anticommons problems, that seem principally to account for the law's restrictive approach to accommodating divided property rights, both overall and in terms of the particular types of rights that are accommodated.

\section{Conclusion}

Both common-law and civil law jurisdictions explicitly recognize only a few categories of divided property rights. At the same time, jurisdictions of both types allow great freedom in constructing divided contractual rights in assets. At bottom, this difference between property rights and contract rights reflects the relative ease of aligning the interests of multiple claim holders who deal with each other directly as compared with the substantial costs, both private and social, of aligning the expectations of rights holders who are strangers, and of providing evidence of those expectations to a court.

This difference between contract and property is quantitative rather than qualitative. Just using the ordinary tools of contract, it is possible with sufficient effort to fashion nonpossessory rights in an asset that will bind thirdparty purchasers. The rules of law that offer explicit recognition of particular types of property rights simply reduce the costs of establishing those rights. Consequently, it is not quite right to say that the law limits the kinds of property rights that can be created. Rather, it is more accurate to say that there are only limited kinds of property rights whose creation the law affirmatively facilitates.

The reason for the law's conservatism in this regard is that reducing the costs of establishing property rights commonly increases costs for nonusers of the rights. An efficient legal regime will therefore offer special accommodation to divided property rights only where the benefits to users of the rights exceed those costs. For a variety of reasons, existing legal systems

believe that, like anticommons problems in general, while they reduce the overall value of divided property rights, they do not bear heavily on the particular structure of divided rights that the law accommodates. 
meet only a rough standard of efficiency in this respect. Nevertheless, the property law regimes we observe clearly reflect, in general terms, the fact that the value of property rights is often too small to justify the costs engendered by the legal rules needed to support them. 